\title{
Barriers to predicting changes in global terrestrial methane fluxes: analyses using CLM4Me, a methane biogeochemistry model integrated in CESM
}

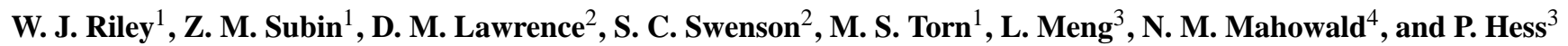 \\ ${ }^{1}$ Earth Sciences Division, Lawrence Berkeley National Laboratory, Berkeley, CA 94720, USA \\ ${ }^{2}$ NCAR Earth System Laboratory, Climate and Global Dynamics Division, National Center for Atmospheric Research, \\ Boulder, CO, USA \\ ${ }^{3}$ Department of Biological and Environmental Engineering, 312 Riley Robb Hall, Cornell University, Ithaca, NY 14850, USA \\ ${ }^{4}$ Department of Earth and Atmospheric Sciences, Cornell University, Snee 2140, Ithaca, NY 14853, USA
}

Received: 25 January 2011 - Published in Biogeosciences Discuss.: 24 February 2011

Revised: 15 June 2011 - Accepted: 20 June 2011 - Published: 20 July 2011

\begin{abstract}
Terrestrial net $\mathrm{CH}_{4}$ surface fluxes often represent the difference between much larger gross production and consumption fluxes and depend on multiple physical, biological, and chemical mechanisms that are poorly understood and represented in regional- and global-scale biogeochemical models. To characterize uncertainties, study feedbacks between $\mathrm{CH}_{4}$ fluxes and climate, and to guide future model development and experimentation, we developed and tested a new $\mathrm{CH}_{4}$ biogeochemistry model (CLM4Me) integrated in the land component (Community Land Model; CLM4) of the Community Earth System Model (CESM1). CLM4Me includes representations of $\mathrm{CH}_{4}$ production, oxidation, aerenchyma transport, ebullition, aqueous and gaseous diffusion, and fractional inundation. As with most global models, CLM4 lacks important features for predicting current and future $\mathrm{CH}_{4}$ fluxes, including: vertical representation of soil organic matter, accurate subgrid scale hydrology, realistic representation of inundated system vegetation, anaerobic decomposition, thermokarst dynamics, and aqueous chemistry. We compared the seasonality and magnitude of predicted $\mathrm{CH}_{4}$ emissions to observations from 18 sites and three global atmospheric inversions. Simulated net $\mathrm{CH}_{4}$ emissions using our baseline parameter set were 270, 160 , 50, and $70 \mathrm{Tg} \mathrm{CH}_{4} \mathrm{yr}^{-1}$ globally, in the tropics, in the temperate zone, and north of $45^{\circ} \mathrm{N}$, respectively; these values are within the range of previous estimates. We then used the model to characterize the sensitivity of regional and global $\mathrm{CH}_{4}$ emission estimates to uncertainties in model pa-
\end{abstract}

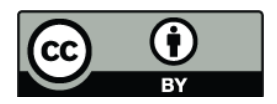

Correspondence to: W. J. Riley

(wjriley@lbl.gov) rameterizations. Of the parameters we tested, the temperature sensitivity of $\mathrm{CH}_{4}$ production, oxidation parameters, and aerenchyma properties had the largest impacts on net $\mathrm{CH}_{4}$ emissions, up to a factor of 4 and 10 at the regional and gridcell scales, respectively. In spite of these uncertainties, we were able to demonstrate that emissions from dissolved $\mathrm{CH}_{4}$ in the transpiration stream are small $\left(<1 \mathrm{Tg} \mathrm{CH}_{4} \mathrm{yr}^{-1}\right)$ and that uncertainty in $\mathrm{CH}_{4}$ emissions from anoxic microsite production is significant. In a 21 st century scenario, we found that predicted declines in high-latitude inundation may limit increases in high-latitude $\mathrm{CH}_{4}$ emissions. Due to the high level of remaining uncertainty, we outline observations and experiments that would facilitate improvement of regional and global $\mathrm{CH}_{4}$ biogeochemical models.

\section{Introduction}

Methane $\left(\mathrm{CH}_{4}\right)$ is the second most important anthropogenic greenhouse gas, currently contributing about $\frac{1}{3}$ the anthropogenic radiative forcing of $\mathrm{CO}_{2}$ (Denman et al., 2007). Dominant sources of $\mathrm{CH}_{4}$ to the atmosphere include fossil fuel extraction and use, wetlands, ruminants, rice agriculture, and landfills (Denman et al., 2007). Currently, of the $\sim 500-600 \mathrm{Tg} \mathrm{CH}_{4} \mathrm{yr}^{-1}$ emitted to the atmosphere globally, $\sim 20-40 \%$ originate in wetlands, and $\sim 5 \%$ are oxidized in unsaturated soils. Over the past several decades, the atmospheric $\mathrm{CH}_{4}$ growth rate has varied considerably, with changes in fossil fuel emissions (Khalil and Shearer, 2000; Bousquet et al., 2006), atmospheric sinks (Dentener et al., 2003; Karlsdottir and Isaksen, 2000), and fertilizer and

Published by Copernicus Publications on behalf of the European Geosciences Union. 
irrigation management in rice agriculture (Kai et al., 2010) proposed as explanations.

Methane emissions from terrestrial ecosystems have the potential to form positive feedbacks to climate change. Highlatitude ecosystems are of particular concern, since they are expected to experience large changes in temperature and precipitation and contain large amounts of potentially labile soil organic matter that is currently preserved by permafrost or anoxia (Schuur et al., 2008). The largest wetland complex in the world resides at high latitudes (MacDonald et al., 2006) and contributes $10-30 \%$ of global $\mathrm{CH}_{4}$ emissions from natural wetlands (Wania et al., 2009; Christensen et al., 1996; Zhuang et al., 2004; Bergamaschi et al., 2009). Interactions of these systems with expected 21st century climate change could result in changing $\mathrm{CH}_{4}$ emissions through several mechanisms: (1) thawing permafrost releasing currently dormant soil carbon for degradation (Schuur et al., 2009; Anisimov et al., 2007) and altering surface hydrology via thermokarst (Walter et al., 2007); (2) changes in the kinetics of soil biogeochemistry with increasing temperature (Segers, 1998); (3) changes in hydrology interacting with peat properties and active layer depth (Smith et al., 2003); and (4) changes in net primary productivity (NPP) and plant type distributions (Christensen et al., 2004).

In addition to these decadal-scale changes, the net terrestrial $\mathrm{CH}_{4}$ surface flux depends non-linearly on very dynamic (i.e., time scale on the order of an hour) interactions between $\mathrm{CH}_{4}$ production; $\mathrm{CH}_{4}$ oxidation; aqueous, gaseous, and aerenchyma transport; acid and redox chemistry; and the distribution of soil and surface water. This complex set of interactions and dependence on system properties is difficult to characterize and model globally, making current large-scale $\mathrm{CH}_{4}$ emission estimates uncertain. However, the potentially large climate forcing associated with changes in $\mathrm{CH}_{4}$ emissions motivates the development of land models capable of characterizing these processes and their interactions with the atmosphere.

Grant and Roulet (2002) and Wania et al. (2010) described a hierarchy of extant bottom-up ecosystem $\mathrm{CH}_{4}$ biogeochemical models. Briefly, this hierarchy includes (1) relatively simple regressions of net $\mathrm{CH}_{4}$ fluxes based on soil properties and climate (Frolking and Crill, 1994; Bellisario et al., 1999; Moore and Roulet, 1993; Christensen et al., 1996; Kaplan, 2002); (2) models that estimate daily fluxes dependent on water chemistry, temperature, and estimates of the C flux moving through the soil system (Potter, 1997); (3) models applied at site, regional, and global scales that include aqueous and gaseous transport, competition between processes affecting $\mathrm{CH}_{4}$ concentrations, and simple representations of the effects of $\mathrm{pH}$ and redox potential (Zhang et al., 2002; Walter et al., 2001a; Wania et al., 2010; Zhuang et al., 2004; Cao et al., 1996; Petrescu et al., 2010; Tian et al., 2010); and (4) models that include details of the various microbial populations that produce and consume $\mathrm{CH}_{4}$ in the column and their interactions with substrates, $\mathrm{pH}$, and redox poten- tial, in addition to some treatment of the geometry of the rhizosphere and soil horizontal heterogeneity (Grant, 1998, 1999; Segers et al., 2001; Segers and Leffelaar, 2001a, b). An important further distinction in model characterization is the extent to which they are applicable to regional and global scale simulations, where it is often difficult to specify system properties (e.g., redox potential, $\mathrm{pH}$ ).

A wide range of bottom-up estimates of current highlatitude $\mathrm{CH}_{4}$ fluxes exists in the literature. Zhuang et al. (2004) synthesized several modeling studies and found a range of 31-106 $\mathrm{TgCH}_{4} \mathrm{yr}^{-1}$. More recently, for fluxes north of $50^{\circ} \mathrm{N}$, Zhuang et al. (2006) estimated emissions of $36 \mathrm{TgCH}_{4} \mathrm{yr}^{-1}$ and Petrescu et al. (2010) estimated a six-year annual average high-latitude emission of $78 \mathrm{Tg} \mathrm{CH}_{4} \mathrm{yr}^{-1}$. In addition to differences in parameterization, the models used in these analyses differed in their characterization of important system attributes, including aerenchyma characteristics, wetland area and type, seasonal inundation, aqueous chemistry, the competition for oxygen in the rhizosphere, and the extent to which methanogens are substrate or kinetically limited. There are fewer bottom-up $\mathrm{CH}_{4}$ emission estimates for tropical systems, with a wide variation in estimates. For example, Walter et al. (2001a) and Matthews and Fung (1987) estimated 184 and $35 \mathrm{Tg} \mathrm{CH}_{4} \mathrm{yr}^{-1}$, respectively, for tropical systems.

Recently, a new mechanism has been proposed for aerobic $\mathrm{CH}_{4}$ production in living trees that could represent a source of $62-236 \mathrm{Tg} \mathrm{CH}_{4} \mathrm{yr}^{-1}$ (Keppler et al., 2006; Keppler, 2009). However, mechanistic explanation for this source remains uncertain (Ferretti et al., 2007), and independent verification of its magnitude has not been demonstrated. Alternative hypotheses to explain such a large $\mathrm{CH}_{4}$ source include abiotic chemistry in stressed and UV-exposed plant tissue or emission of anaerobically produced $\mathrm{CH}_{4}$ dissolved in soil water via transpiration (Nisbet et al., 2009; Rice et al., 2010). We included in our model an option for allowing transpiration of $\mathrm{CH}_{4}$ dissolved in soil water to estimate the potential magnitude of global emissions from this mechanism.

A large literature exists on the use of atmospheric inversions ("top-down" approaches) to infer surface $\mathrm{CH}_{4}$ emissions (Butler et al., 2005; Dentener et al., 2003; Kort et al., 2008; Straume et al., 2005; Houweling et al., 1999, 2000, 2006; Meirink et al., 2006, 2008a, b; Bergamaschi et al., 2001, 2005, 2007, 2009; Bousquet et al., 2006; Chen and Prinn, 2006; Frankenberg et al., 2006, 2008; Bloom et al., 2010). These methods require a combination of atmospheric $\mathrm{CH}_{4}$ observations, atmospheric transport fields, atmospheric hydroxyl radical concentrations, and a priori estimates of surface $\mathrm{CH}_{4}$ emissions. Often, anthropogenic and other biogenic emissions are set from previous work. For example, Bloom et al. (2010) used satellite observations of atmospheric $\mathrm{CH}_{4}$ concentrations, estimates of inundation inferred from the GRACE satellite, and an inversion framework to estimate global terrestrial $\mathrm{CH}_{4}$ emissions. They concluded 
that tropical wetlands contribute $52-58 \%$ of global wetland emissions, and that 2003-2007 $\mathrm{CH}_{4}$ emissions rose by $7 \%$ as a result of warming in mid- and Arctic latitudes. Bergamaschi et al. (2009) used the recently revised ENVISAT satellite observations and NOAA ship and aircraft profile samples to invert for global surface $\mathrm{CH}_{4}$ emissions. They estimated that, on average, $76 \%$ of annual global wetland and rice emissions occurred in the tropics.

Several studies have used land-surface biogeochemical models to predict $\mathrm{CH}_{4}$ emissions over the 21 st century; the majority of these studies have concluded that changes in $\mathrm{CH}_{4}$ emissions from northern wetlands will be positive and modest compared to expected increases in anthropogenic emissions. For example, both Zhuang et al. (2006) and Gedney et al. (2004) predict about a doubling of high-latitude wetland terrestrial $\mathrm{CH}_{4}$ emissions over the century. Bohn et al. (2007) estimated that $\mathrm{CH}_{4}$ emissions would about double over the 21 st century for a $100 \times 100 \mathrm{~km}$ region in Western Siberia. Shindell et al. (2004) suggested that, in a doubled $\mathrm{CO}_{2}$ experiment, global emissions would rise by $78 \%$ (dominated by increased tropical wetland emissions) and high northern latitude wetland emissions would triple during Northern summer. Volodin (2008), using a simple terrestrial $\mathrm{CH}_{4}$ emission model coupled into a GCM, simulated an increase in atmospheric burden of $300 \mathrm{ppb} \mathrm{CH}_{4}$ and $0.25^{\circ} \mathrm{C}$ of additional warming at the end of the 21st century. Although these $\mathrm{CH}_{4}$ emission estimates are relatively small in the context of expected 21 st century anthropogenic emissions, we note that some features critical to $\mathrm{CH}_{4}$ production and emissions are poorly represented in these models (e.g., permafrost dynamics, thermokarst lake dynamics, dynamic vegetation), and that inclusion of these mechanisms could substantially alter predicted net fluxes. We are not aware of estimates of future $\mathrm{CH}_{4}$ emissions from tropical terrestrial systems.

The broad goals of the current work are (1) develop, test, and integrate into CESM1 a mechanistic treatment of terrestrial $\mathrm{CH}_{4}$ production, consumption, and transport processes; (2) apply the model (CLM4Me) to characterize uncertainties in current large-scale $\mathrm{CH}_{4}$ emission estimates; and (3) help guide future model development, observation, and experiments necessary to improve this class of biogeochemical models. Ultimately, CLM4Me will allow global coupled $\mathrm{CH}_{4}$ simulations integrated with the atmospheric chemistry model of CESM1. After describing the processes represented in CLM4Me, we present comparisons between predictions and observations at 18 sites and three global atmospheric inversions. We also describe analyses of the controls on $\mathrm{CH}_{4}$ transport through aerenchyma, the sensitivity of $\mathrm{CH}_{4}$ emissions to aerenchyma area, and a year 2100 highlatitude emissions sensitivity in the absence of the release of permafrost carbon and changes in plant distribution and productivity. Finally, we used CLM4Me to elucidate experimental and observational studies and analyses that would benefit bottom-up modeling of large-scale $\mathrm{CH}_{4}$ emissions.

\section{Methods}

\subsection{CLM4 $\mathrm{CH}_{4}$ biogeochemistry model (CLM4Me) description}

We have integrated CLM4Me, a $\mathrm{CH}_{4}$ biogeochemistry model, into CLM4 (Lawrence et al., 2011; Oleson et al., 2010), the land model integrated in the Community Climate System Model (CCSM4; Gent et al., 2010) and the Community Earth System Model (CESM1). CLM4 includes modules to simulate (1) plant photosynthesis, respiration, growth, allocation, and tissue mortality; (2) energy, radiation, water, and momentum exchanges with the atmosphere; (3) soil heat, moisture, carbon, and nitrogen dynamics; (4) surface runoff and groundwater interactions; and (5) snow and soil ice dynamics, among others. Having a representation of these processes with some level of detail is important for estimating the controlling factors for $\mathrm{CH}_{4}$ production, consumption, and emission to the atmosphere.

Many aspects of CLM4 have been described elsewhere and several versions of the model have been tested and evaluated at the global (Lawrence et al., 2007; Oleson et al., 2008; Randerson et al., 2009; Lawrence and Slater, 2008) and site (Stockli et al., 2008; Randerson et al., 2009) scales. Here we briefly describe CLM4 components relevant to the $\mathrm{CH}_{4}$ biogeochemistry model. CLM4 characterizes vegetation as plant functional types (PFTs), which occupy static or dynamic fractions of each grid cell (Bonan et al., 2002). The PFTs ( 8 tree, 3 shrub, 3 grass, and 2 crop types) are characterized by distinct physiological parameters (Oleson et al., 2010). For each PFT, separate temperature and humidity are computed for canopy air, near-surface air, and the leaf surface, and the PFTs compete for soil water within each grid cell. A detailed representation of $\mathrm{C}$ assimilation, plant growth and mortality, allocation of $\mathrm{C}$ and $\mathrm{N}$ within the plant, and subsurface $\mathrm{C}$ and $\mathrm{N}$ cycling has been integrated in the model (Thornton et al., 2007). Over time, $\mathrm{C}$ and $\mathrm{N}$ from various plant components are passed to litter and soil pools, each of which have specific turnover times that are modified by temperature, moisture, and $\mathrm{N}$ constraints. The resulting soil $\mathrm{C}$ fluxes form an important link to the $\mathrm{CH}_{4}$ biogeochemistry, since they are the proximal $\mathrm{C}$ source for methanogenesis.

Mechanistically modeling net surface $\mathrm{CH}_{4}$ emissions requires representing a complex and often interacting series of processes. To simulate the flux of substrate available for methanogenesis, the model must represent net primary productivity (NPP), the transfer of that $\mathrm{C}$ to litter and ultimately to soil organic matter (SOM), and then the decomposition of SOM. For the current $\mathrm{CH}_{4}$ model, we apply the existing structure in CLM4 for these processes. In anaerobic soils, fermenting microbes and $\mathrm{H}_{2}$-producing acetogens transform organic molecules, ultimately producing acetate, $\mathrm{H}_{2}$, and $\mathrm{CO}_{2}$. In freshwater anaerobic systems, acetate and $\mathrm{H}_{2}$ are the primary substrates utilized by two classes of methanogens (acetotrophic and hydrogenotrophic), producing $\mathrm{CH}_{4}$ as a 


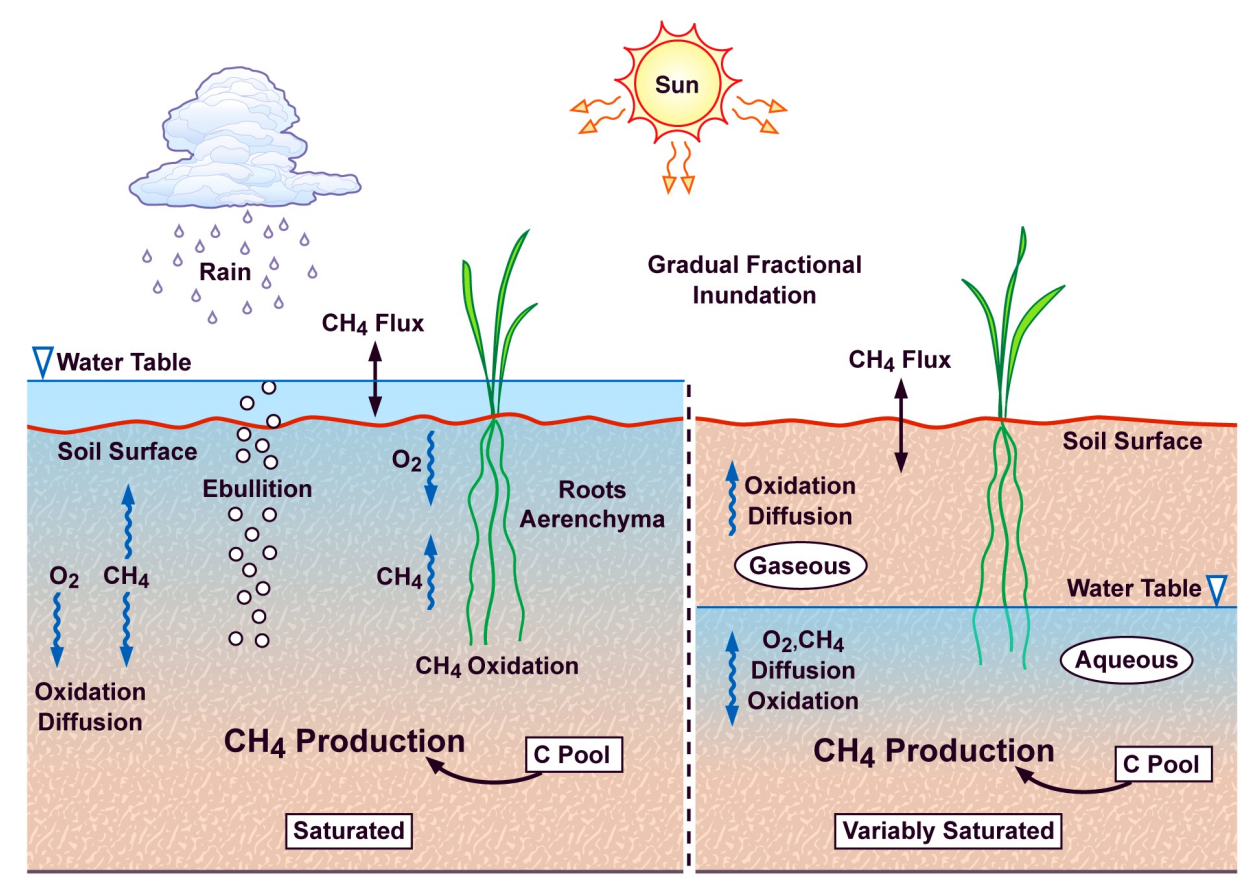

Fig. 1. Schematic representation of biological and physical processes integrated in CLM4Me that affect the net $\mathrm{CH}_{4}$ surface flux. (left) Fully inundated portion of a CLM4 gridcell and (right) variably saturated portion of a gridcell.

byproduct (Megonigal et al., 2004; Segers, 1998). The presence of alternative electron acceptors (e.g., $\mathrm{NO}_{3}^{-}, \mathrm{Fe}^{3+}$, $\mathrm{Mn}^{4+}, \mathrm{SO}_{4}^{2-}$ ) suppresses $\mathrm{CH}_{4}$ production via: (1) reduction of $\mathrm{C}$ substrate levels; (2) increase in redox potential; and (3) toxicity to methanogens (Segers and Kengen, 1998). If the redox potential is sufficiently high, anaerobic decomposition to $\mathrm{CO}_{2}$ will out-compete methanogenesis. Once $\mathrm{CH}_{4}$ has been produced, it can be oxidized by methanotrophs or transported vertically via ebullition (bubbling), diffusion, and aerenchymous tissues in plants. In some cases, oxidation may result in a net zero surface emission. Also, transport in aerenchyma can be either passive (i.e., diffusive) or active (from pressure gradients), and occurs for both $\mathrm{CH}_{4}$ and $\mathrm{O}_{2}$. Further details of these processes relevant to the modeling framework used in CLM4Me are given in the Methods subsections below.

The development of complex models (like CLM4Me) requires a balance between the desire to include all mechanisms hypothesized to be important and restrictions based on (1) uncertainty in assumed system structure; (2) uncertain parameter characterization; (3) uncertainties associated with spatial heterogeneity; (4) limited availability of measurements to develop, test, and perform simulations; (5) uncertainty in boundary and initial conditions; and (6) computational resources. All of these limitations are relevant to CLM4Me, particularly for regional to global applications. As we discuss below, the available literature provides limited constraints on many important model parameters (e.g., half-saturation coefficients and maximum potential rate for oxidation, temperature dependence of methanogen productivity), the effects of competition between processes (e.g., aerenchyma transport versus oxidation by methanotrophs in the rhizosphere), and the spatial distributions of state variables affecting $\mathrm{CH}_{4}$ production and oxidation (e.g., $\mathrm{pH}$, redox potential, inundation), among others. We attempted to account for these limitations and ascertain their affects on model uncertainty as best as possible; however, we expect the model structure and parameterization will improve as more information becomes available.

\subsubsection{Governing mass-balance relationship}

CLM4Me simulates the transient, vertically resolved dynamics of $\mathrm{CH}_{4}$ and $\mathrm{O}_{2}$ in the soil column (Fig. 1). For $\mathrm{CH}_{4}$, the model accounts for production in the anaerobic fraction of soil $\left(P, \mathrm{~mol} \mathrm{~m}^{-3} \mathrm{~s}^{-1}\right)$, ebullition $(E$, mol m$\left.{ }^{-3} \mathrm{~s}^{-1}\right)$, aerenchyma transport $\left(A, \operatorname{mol~m}^{-3} \mathrm{~s}^{-1}\right)$, aqueous and gaseous diffusion $\left(F_{\mathrm{D}}, \mathrm{mol} \mathrm{m}^{-2} \mathrm{~s}^{-1}\right)$, and oxidation $\left(O, \mathrm{~mol} \mathrm{~m}^{-3} \mathrm{~s}^{-1}\right)$ via a transient reaction diffusion equation:

$$
\frac{\partial(R C)}{\partial t}=\frac{\partial F_{\mathrm{D}}}{\partial z}+P(z, t)-E(z, t)-A(z, t)-O(z, t) .
$$

Here $z(\mathrm{~m})$ represents the vertical dimension, $t(\mathrm{~s})$ is time, and $R$ accounts for gas in both the aqueous and gaseous phases: $R=\varepsilon_{\mathrm{a}}+K_{\mathrm{H}} \varepsilon_{\mathrm{w}}$, with $\varepsilon_{\mathrm{a}}, \varepsilon_{\mathrm{w}}$, and $K_{\mathrm{H}}(-)$ the air-filled porosity, water-filled porosity, and partitioning coefficient for the species of interest, respectively. An analogous version of 
Eq. (1) is concurrently solved for $\mathrm{O}_{2}$, but with the following differences relative to $\mathrm{CH}_{4}: P=E=0$ (i.e., no production or ebullition), the aerenchyma transport is a source rather than a sink, and the oxidation sink includes the $\mathrm{O}_{2}$ demanded by methanotrophs, heterotrophs, and autotrophic root respiration.

As currently implemented, each gridcell contains an inundated and a non-inundated fraction. Therefore, Eq. (1) is solved four times for each gridcell and time step: in the inundated and non-inundated fractions, and for $\mathrm{CH}_{4}$ and $\mathrm{O}_{2}$. For non-inundated areas, the water table interface is defined at the lowest transition from greater than $95 \%$ saturated to less than $95 \%$ saturated that occurs above frozen soil layers. The inundated fraction is allowed to change at each time step, and the total soil $\mathrm{CH}_{4}$ quantity is conserved by evolving $\mathrm{CH}_{4}$ to the atmosphere when the inundated fraction decreases, and averaging a portion of the non-inundated concentration into the inundated concentration when the inundated fraction increases. In future studies we plan to include the $\mathrm{CH}_{4}$ biogeochemistry modeling in our representation of lakes, which implies that Eq. (1) will be solved an additional two times for each gridcell where lakes are present.

The CLM4Me structure and process representation benefited from descriptions of several previous models, including LPJ-WHYMe (Wania et al., 2010), TEM (Zhuang et al., 2004), and the model of Walter and Heimann (2000). However, several improvements have been integrated into CLM4Me, including representations of (1) the time-varying inundated fraction; (2) prognostic transport of $\mathrm{O}_{2}$ through aerenchyma and competition for $\mathrm{O}_{2}$ by oxidizers in the rhizosphere; (3) $\mathrm{CH}_{4}$ production and oxidation in upland soils; (4) the effect of seasonal inundation on substrate availability; and (5) a coupled reaction and diffusion numerical scheme.

\subsection{2 $\mathrm{CH}_{4}$ production}

CLM4 does not currently have a wetland representation that includes details relevant to $\mathrm{CH}_{4}$ production (e.g., wetlandspecific plants, anoxia controls on SOM turnover), nor is the inundated fraction used by the $\mathrm{CH}_{4}$ submodel integrated with the CLM4 soil hydrology and temperature predictions. We therefore used gridcell-averaged decomposition rates as proxies for the wetland fluxes and are planning to improve on this simplification in future work. In CLM4Me, $\mathrm{CH}_{4}$ production in the anaerobic portion of the soil column is related to the gridcell estimate of heterotrophic respiration from soil and litter $\left(R_{\mathrm{H}} ; \mathrm{mol} \mathrm{C} \mathrm{m}^{-2} \mathrm{~s}^{-1}\right)$ corrected for its soil temperature $\left(T_{\mathrm{S}}\right)$ dependence, soil temperature through a $Q_{10}$ factor $\left(f_{T}\right), \mathrm{pH}\left(f_{\mathrm{pH}}\right.$; Meng et al., 2011), redox potential $\left(f_{\mathrm{pE}}\right)$, and a factor accounting for the seasonal inundation fraction $(S$, described below):

$P=R_{\mathrm{H}} f_{\mathrm{CH}_{4}} f_{T} f_{\mathrm{pH}} f_{\mathrm{pE}} S$.

Here, $f_{\mathrm{CH}_{4}}$ is the baseline fraction of anaerobically mineralized $\mathrm{C}$ atoms becoming $\mathrm{CH}_{4}$ (all parameters values are given in Table 1). Assuming that $\mathrm{CH}_{4}$ production is directly related to heterotrophic respiration implies the assumption that there are no time delays between fermentation and $\mathrm{CH}_{4}$ production, and that soil organic matter can be treated uniformly with respect to its decomposition under either aerobic or anaerobic conditions. We set $f_{T}=0$ for temperatures equal to or below freezing, even though CLM4 allows heterotrophic respiration below freezing. Our base temperature for the $Q_{10}$ factor, $T_{\mathrm{B}}$, is $22^{\circ} \mathrm{C}$. Although the CLM4 soil organic model is not vertically resolved, we distribute $R_{\mathrm{H}}$ among soil levels by assuming that $50 \%$ is associated with the roots (using the CLM4 PFT-specific rooting distribution) and the rest is evenly divided among the top $0.28 \mathrm{~m}$ of soil (to be consistent with CLM4's soil decomposition algorithm). The factor $f_{\mathrm{pH}}$ is nominally set to 1 ; its impact is tested in our sensitivity analysis by applying the method of Meng et al. (2011). The $f_{\mathrm{pE}}$ sensitivity assumes that the alternative electron acceptors are reduced with an e-folding time of 30 days after inundation. The default version of the model applies this factor to horizontal changes in inundated area but not to vertical changes in the water table depth in the upland fraction of the gridcell. Other large-scale models such as TEM (Zhuang et al., 2004), LPJ-WHyMe (Wania et al., 2010), and that of Walter et al. (2001a) used production relationships analogous to Eq. (2). However, in these models $R_{\mathrm{H}}$ was (1) set from observations in six high-latitude sites in TEM; (2) set from observations in six mid- and highlatitude sites (Walter et al., 2001a); and (3) related to exudation and heterotrophic respiration in LPJ-WHyMe. Wania et al. (2010) argued that the $\mathrm{pH}$ and redox factors are so poorly characterized that they should be excluded. We discuss in the Results and Discussion sections below the ranges of parameter values reported in the literature and how uncertainty in some of the parameters propagates to uncertainty in regional and global $\mathrm{CH}_{4}$ emission estimates.

We have also included in CLM4Me the effect of seasonal inundation, which has been ignored in previous models. Particularly in tropical systems, where both warm-wet and warm-dry seasons occur, $\mathrm{SOM}$ and $\mathrm{CH}_{4}$ dynamics in a seasonally inundated system will be different than either upland or continuously inundated systems. In the continuously inundated wetland, anoxia suppresses decomposition, leading to a larger SOM stock, partially compensating the effect of anoxia on decomposition rates. The compensation is complete (i.e., respiration rates are unchanged) if (1) soil decomposition is a linear function of pool size; (2) the fully anaerobic decomposition rate is a fixed factor of the aerobic rate; and (3) the soil is in equilibrium. In contrast, a tropical seasonally inundated system may experience extensive decomposition during the dry season but emit most of its $\mathrm{CH}_{4}$ during the wet season. Because the equilibrium carbon stock will be smaller, the $\mathrm{CH}_{4}$ fluxes will be smaller than the annual wetland even during the wet season. Modeling these dynamics explicitly would require dividing the gridcell into an array of columns with different seasonal hydrological 
Table 1. Parameter descriptions and sensitivity analysis ranges applied in the model.

\begin{tabular}{|c|c|c|c|c|c|}
\hline Mechanism & Parameter & Baseline Value & Range for Sensitivity Analysis & Units & Description \\
\hline \multirow[t]{6}{*}{ Production } & $Q_{10}$ & 2 & $1.5-4$ & - & $\mathrm{CH}_{4}$ production $Q_{10}$ \\
\hline & $f_{\mathrm{pH}}$ & 1 & On, off & - & Impact of $\mathrm{pH}$ on $\mathrm{CH}_{4}$ production \\
\hline & $f_{\mathrm{pE}}$ & 1 & On, off & - & $\begin{array}{l}\text { Impact of redox potential on } \mathrm{CH}_{4} \\
\text { production }\end{array}$ \\
\hline & $S$ & Varies & NA & - & Seasonal inundation factor \\
\hline & $\beta$ & 0.2 & NA & - & $\begin{array}{l}\text { Effect of anoxia on decomposition } \\
\text { rate (used to calculate } S \text { only) }\end{array}$ \\
\hline & $f_{\mathrm{CH}_{4}}$ & 0.2 & NA & - & $\begin{array}{l}\text { Fraction of anaerobically } \\
\text { mineralized } \mathrm{C} \text { atoms becoming } \mathrm{CH}_{4}\end{array}$ \\
\hline \multirow[t]{2}{*}{ Ebullition } & $C_{\mathrm{e}, \max }$ & 0.15 & NA & - & $\mathrm{CH}_{4}$ concentration to start ebullition \\
\hline & $C_{\mathrm{e}, \min }$ & 0.15 & NA & - & $\mathrm{CH}_{4}$ concentration to end ebullition \\
\hline Diffusion & $f_{\mathrm{D}_{0}}$ & 1 & 1,10 & - & $\begin{array}{l}\text { Diffusion coefficient multiplier } \\
\text { (Table 2) }\end{array}$ \\
\hline \multirow[t]{4}{*}{ Aerenchyma } & $p$ & 0.3 & NA & - & Grass aerenchyma porosity \\
\hline & $R$ & $2.9 \times 10^{-3}$ & NA & $\mathrm{m}$ & Aerenchyma radius \\
\hline & $r_{\mathrm{L}}$ & 3 & NA & - & Root length to depth ratio \\
\hline & $F_{\mathrm{a}}$ & 1 & $0.2-2.0$ & - & Aerenchyma conductance multiplier \\
\hline \multirow[t]{3}{*}{ Oxidation } & $K_{\mathrm{CH}_{4}}$ & $5 \times 10^{-3}$ & $5 \times 10^{-4}-5 \times 10^{-2}$ & $\mathrm{~mol} \mathrm{~m}^{-3}$ & $\begin{array}{l}\mathrm{CH}_{4} \text { half-saturation oxidation } \\
\text { coefficient (wetlands) }\end{array}$ \\
\hline & $K_{\mathrm{O}_{2}}$ & $2 \times 10^{-2}$ & $2 \times 10^{-3}-2 \times 10^{-1}$ & $\mathrm{~mol} \mathrm{~m}^{-3}$ & $\begin{array}{l}\mathrm{O}_{2} \text { half-saturation oxidation } \\
\text { coefficient }\end{array}$ \\
\hline & $R_{\mathrm{O}, \max }$ & $1.25 \times 10^{-5}$ & $1.25 \times 10^{-6}-1.25 \times 10^{-4}$ & $\mathrm{~mol} \mathrm{~m}^{-3} \mathrm{~s}^{-1}$ & Maximum oxidation rate (wetlands) \\
\hline
\end{tabular}

regimes. In CLM4Me, we have developed a simplified scaling factor to mimic the impact of seasonal inundation on $\mathrm{CH}_{4}$ production:

$S=\frac{\beta(f-\bar{f})+\bar{f}}{f}, S \leq 1$.

where $f$ is the instantaneous inundated fraction, $\bar{f}$ is the annual average inundated fraction (evaluated for the previous calendar year) weighted by heterotrophic respiration, and $\beta$ is the anoxia factor that relates the fully anoxic decomposition rate to the fully oxygen-unlimited decomposition rate, all other conditions being equal. See Appendix B for further discussion of seasonal inundation.

Some researchers have suggested that $\mathrm{CH}_{4}$ could be produced in anoxic microsites in otherwise aerobic soil above the water table. For example, Arah and Stephen (1998) assumed that production is inhibited by a factor dependent on the gas phase $\mathrm{O}_{2}$ concentration. Arah and Vinten (1995), Rappoldt and Crawford (1999), and Schurgers et al. (2006) discuss more complicated approaches to estimating anoxic soil volume fraction based on soil properties and the rate of oxygen consumption. We note that one reason $\mathrm{CH}_{4}$ production may not be analogous to denitrification is that alternative electron acceptors that inhibit $\mathrm{CH}_{4}$ production may persist in anoxic microsites. As a sensitivity case, we examined the effects on global $\mathrm{CH}_{4}$ flux and atmospheric methane uptake of including production in anoxic microsites according to the Arah and Stephen (1998) expression:

$\varphi=\frac{1}{1+\eta C_{\mathrm{O}_{2}}}$.

Here, $\varphi$ is the factor by which production is inhibited above the water table (compared to production as calculated in Eq. 2), $C_{\mathrm{O}_{2}}\left(\mathrm{~mol} \mathrm{~m}^{-3}\right)$ is the bulk soil oxygen concentration, and $\eta=400 \mathrm{~m}^{3} \mathrm{~mol}^{-1}$.

\subsubsection{Ebullition}

Our representation of ebullition fluxes follows that of Wania et al. (2010). Briefly, the simulated aqueous $\mathrm{CH}_{4}$ concentration in each soil level is used to estimate the expected equilibrium gaseous partial pressure as a function of temperature and pressure. When this partial pressure exceeds $C_{\mathrm{e}, \max }$ (taken as $15 \%$ of the ambient pressure; Baird et al., 2004; Strack et al., 2006; Wania et al., 2010), bubbling occurs to remove $\mathrm{CH}_{4}$ to below this value, modified by the fraction of $\mathrm{CH}_{4}$ in the bubbles (taken as $57 \%$; Kellner et al., 2006; Wania et al., 2010). Bubbles are immediately added to the surface flux for saturated columns and are placed immediately above the water table interface in unsaturated columns. In many systems, physical constraints exist that hinder bubble transport. However, further research is required to develop 
model structures and parameterizations to represent this process in large-scale $\mathrm{CH}_{4}$ biogeochemical models.

\subsubsection{Aerenchyma transport}

Vascular plants that inhabit continuously or seasonally inundated systems must supply $\mathrm{O}_{2}$ to their roots and provide a conduit to remove toxics. Many such plants develop aerenchyma, which are tissues that facilitate exchange between atmospheric $\mathrm{O}_{2}$ and autotrophic root demand in the soil. However, these tissues are also conduits for $\mathrm{CH}_{4}$ and other gases to diffuse from the soil to the atmosphere. $\mathrm{An}_{2}$ molecule within the aerenchyma has several possible fates: consumption by cells within the root tissue, continued diffusion toward the root tips, or diffusion radially to the rhizosphere. Some plants have evolved barriers to radial oxygen loss (at a cost of less efficient water and nutrient uptake), but there can still be substantial loss to the soil surrounding root tips (Colmer, 2003). There is also evidence that methanotrophs exist inside the root tissue (Bosse and Frenzel, 1997). Up to $30-40 \%$ of the $\mathrm{O}_{2}$ supplied in aerenchyma can be lost through radial diffusion to the rhizosphere (Armstrong, 1979), where it can supply other $\mathrm{O}_{2}$ consumers (e.g., methanotrophs). We used the synthesis by Colmer (2003) of the substantial literature on aerenchyma combined with the approach described by Wania et al. (2010) to develop the representation of aerenchyma transport for CLM4Me.

Aerenchyma transport is modeled in CLM4Me as gaseous diffusion driven by a concentration gradient between the specific soil layer and the atmosphere. There is evidence that pressure-driven flow can also occur, but we did not include that mechanism in the current model. Pressure-driven flow may have a relatively small effect on $\mathrm{O}_{2}$ and $\mathrm{CH}_{4}$ fluxes (Wania et al., 2010), although some studies contend the opposite (e.g., Chanton et al., 1993; Chanton and Whiting, 1996; Whiting and Chanton, 1996; Ding and Cai, 2007). The diffusive transport through aerenchyma $\left(A\right.$, mol m$\left.^{-2} \mathrm{~s}^{-1}\right)$ from each soil layer is represented in the model as:

$A=\frac{C(z)-C_{\mathrm{a}}}{\frac{r_{\mathrm{L}} z}{D p T \rho_{\mathrm{r}}}+r_{\mathrm{a}}}$

where $D$ is the free-air gas diffusion coefficient $\left(\mathrm{m}^{2} \mathrm{~s}^{-1}\right)$; $C(z)\left(\mathrm{mol} \mathrm{m}^{-3}\right)$ is the gaseous concentration at depth $z(\mathrm{~m})$; $r_{\mathrm{L}}$ is the ratio of root length to depth; $p$ is the porosity (-); $T$ is specific aerenchyma area $\left(\mathrm{m}^{2} \mathrm{~m}^{-2}\right) ; r_{\mathrm{a}}$ is the aerodynamic resistance between the surface and the atmospheric reference height $\left(\mathrm{s} \mathrm{m}^{-1}\right)$; and $\rho_{\mathrm{r}}$ is the root fraction in the soil layer (-). Some studies have found that stomatal conductance can control plant-mediated transport in certain species (e.g., Schimel, 1995), but we did not include this mechanism in CLM4Me.

The porosity of aerenchyma varies widely across plant species, between genotypes within a species, between root types (e.g., seminal versus adventitious) of a single species, and along roots. Based on the ranges reported in
Colmer (2003), we have chosen baseline porosity values of 0.3 for grass and crop PFTs and 0.1 for tree and shrub PFTs. The aerenchyma area varies over the course of the growing season; we parameterize this dependency using the simulated leaf area index $L\left(\mathrm{~m}^{2} \mathrm{~m}^{-2}\right)$ :

$T=\frac{f_{N} N_{\mathrm{a}} L}{0.22} \pi R^{2}$.

Here $N_{\mathrm{a}}$ is annual net primary production (NPP, mol m $\left.\mathrm{m}^{-2} \mathrm{~s}^{-1}\right) ; R$ is the aerenchyma radius $\left(2.9 \times 10^{-3} \mathrm{~m}\right)$; $f_{N}$ is the belowground fraction of current NPP; and the 0.22 factor represents the amount of $\mathrm{C}$ per tiller (Wania et al., 2010). These factors are likely to vary between PFTs, and probably within an individual PFT, and were developed for sedges and may not be appropriate for woody pfts. We investigated the sensitivity of the aerenchyma $\mathrm{CH}_{4}$ fluxes to porosity and simulated aerenchyma area below.

In addition to the aerenchyma methane flux, CLM4Me simulates the direct emission of methane from leaves to the atmosphere via transpiration of dissolved methane. We used the simulated soil water methane concentration in each soil layer and the CLM4 predicted transpiration for each PFT, assuming that no methane was oxidized inside the plant tissue; this approach is likely to yield an overestimate of the transpiration flux, as methanotrophs can exist inside plant tissue (Bosse and Frenzel, 1997).

\subsection{5 $\mathrm{CH}_{4}$ oxidation}

Heterotrophic methanotrophs are the dominant functional group of microbes that oxidize $\mathrm{CH}_{4}$ in soils, with a rate dependent on $\mathrm{O}_{2}$ and $\mathrm{CH}_{4}$ concentrations, and to a lesser degree $\mathrm{pH}$ and redox potential. Oxidation can be represented with double Michaelis-Menten kinetics (Arah and Stephen, 1998; Segers, 1998), dependent on both the $\mathrm{CH}_{4}$ and $\mathrm{O}_{2}$ concentrations:

$R_{\text {oxic }}=R_{\mathrm{o}, \max }\left[\frac{C_{\mathrm{CH}_{4}}}{K_{\mathrm{CH}_{4}}+C_{\mathrm{CH}_{4}}}\right]\left[\frac{C_{\mathrm{O}_{2}}}{K_{\mathrm{O}_{2}}+C_{\mathrm{O}_{2}}}\right] Q_{10} F_{\vartheta}$

where $K_{\mathrm{CH}_{4}}$ and $K_{\mathrm{O}_{2}}$ are the half saturation coefficients $\left(\mathrm{mol} \mathrm{m}^{-3}\right)$ with respect to $\mathrm{CH}_{4}$ and $\mathrm{O}_{2}$ concentrations, respectively; $R_{\mathrm{O}, \max }$ is the maximum oxidation rate $\left(\mathrm{mol} \mathrm{m}{ }^{-3} \mathrm{~s}^{-1}\right)$; and $Q_{10}$ specifies the temperature dependence of the reaction. The soil moisture limitation factor $F_{\vartheta}$ is applied above the water table to represent water stress for methanotrophs. Based on the data in Schnell and King (1996), $F_{\vartheta}=e^{\frac{-P}{P_{c}}}$, where $P$ is the soil moisture potential and $P_{c}=-2.4 \times 10^{5} \mathrm{~mm}$; this value is roughly consistent with that reported by Gulledge and Schimel (1998). Values for $K_{\mathrm{CH}_{4}}$ in the literature span the range 0.8 to $66.2 \mu \mathrm{M}$ (Segers and Kengen, 1998), and $K_{\mathrm{O}_{2}}$ spans the range 0.3 to $200 \mu \mathrm{M}$ (Segers, 1998). We note that $K_{\mathrm{CH}_{4}}$ and $R_{\mathrm{o} \text {, max }}$ likely vary between uplands and wetlands (Bender and Conrad, 1992) (referred to as "high-affinity" and "low-affinity" methanotrophs, respectively), consistent with evolutionary 
Table 2. Temperature dependence of aqueous and gaseous diffusion coefficients for $\mathrm{CH}_{4}$ and $\mathrm{O}_{2}$.

\begin{tabular}{lll}
\hline$D_{0}\left(\mathrm{~m}^{2} \mathrm{~s}^{-1}\right)$ & $\mathrm{CH}_{4}$ & $\mathrm{O}_{2}$ \\
\hline Aqueous & $0.9798+0.02986 T+0.0004381 T^{2}$ & $1.172+0.03443 T+0.0005048 T^{2}$ \\
\hline Gaseous & $0.1875+0.0013 T$ & $0.1759+0.0011 T$ \\
\hline
\end{tabular}

pressures on the microbial populations. For example, they found that both $K_{\mathrm{CH}_{4}}$ and $R_{\mathrm{O} \text {, max }}$ are more than 100 times larger for the low-affinity methanotrophs active in wetlands. Whalen and Reeburgh (1996) found about a 10-fold higher $K_{\mathrm{CH}_{4}}$ for their sites in Alaska; we assumed a 10-fold ratio for both parameters for our base parameter set.

CLM4Me simulates microbial competition for $\mathrm{O}_{2}$ by first calculating unlimited $\mathrm{O}_{2}$ demands for heterotrophic respiration, autotrophic respiration, and methanotrophy. If the total demand exceeds available $\mathrm{O}_{2}$, the individual demands are scaled proportionately so that all of the $\mathrm{O}_{2}$ is consumed.

\subsubsection{Aqueous and gaseous diffusion}

The diffusivity of gases in water and air depend on the gas species, soil structure, and temperature. For gaseous diffusion, we adopted the temperature dependence of molecular free-air diffusion coefficients $\left(D_{0}\left(\mathrm{~m}^{2} \mathrm{~s}^{-1}\right)\right)$ as described by Lerman (1979) and applied by Wania et al. (2010) (Table 2).

Gaseous diffusivity in soils also depends on the molecular diffusivity, soil structure, porosity, and organic matter content. Moldrup et al. (2003), using observations across a range of unsaturated mineral soils, showed that the relationship between effective diffusivity $\left(D_{\mathrm{e}}\left(\mathrm{m}^{2} \mathrm{~s}^{-1}\right)\right)$ and soil properties can be represented as:

$D_{\mathrm{e}}=D_{0} \theta_{\mathrm{a}}^{2}\left(\frac{\theta_{\mathrm{a}}}{\theta_{\mathrm{s}}}\right)^{\frac{3}{5}}$

where $\theta_{\mathrm{a}}$ and $\theta_{\mathrm{s}}$ are the air-filled and total (saturated waterfilled) porosities (-), respectively, and $b$ is the slope of the water retention curve $(-)$. However, Iiyama and Hasegawa (2005) have shown that the original MillingtonQuirk (Millington and Quirk, 1961) relationship matched measurements more closely in unsaturated peat soils:

$D_{\mathrm{e}}=D_{0} \frac{\theta_{\mathrm{a}}^{\frac{10}{3}}}{\theta_{\mathrm{s}}^{2}}$.

In CLM4Me, we applied Eq. (8) for soils with zero organic matter content and Eq. (9) for soils with more than $130 \mathrm{~kg} \mathrm{~m}^{-3}$ organic matter content. A linear interpolation between these two limits is applied for soils with SOM content below $130 \mathrm{~kg} \mathrm{~m}^{-3}$. For aqueous diffusion in the saturated part of the soil column, we applied (Moldrup et al., 2003):

$D_{\mathrm{e}}=D_{0} \theta_{\mathrm{s}}^{2}$.
To simplify the solution, we assumed that gaseous diffusion dominates above the water table interface and aqueous diffusion below the water table interface. Descriptions, baseline values, and dimensions for parameters specific to the $\mathrm{CH}_{4}$ model are given in Table 1 .

Mastepanov et al. (2008) observed a surge of methane emissions at high-latitude sites during fall freeze-up; they hypothesized that this flux resulted from methane being forced out of freezing soil pores. As a rough sensitivity analysis, we simulated this effect by excluding methane from dissolving in the ice fraction of the soil pore space, thus increasing the concentration in the remaining aqueous and gaseous fractions.

\subsubsection{Boundary conditions and reactive transport solution}

The flux at the soil surface is calculated using the difference between the atmospheric concentration and either the gaseous concentration in the first soil layer (non-saturated soils) or in equilibrium with the water (inundated soil). The model uses the surface-layer aerodynamic resistance determined in CLM4 and the diffusivity through the top half of the top soil layer to calculate the surface flux to the atmospheric reference height. When snow is present, a resistance is added to account for diffusion through the snow based on the Millington-Quirk expression (Eq. 9) and CLM4's prediction of the liquid water, ice, and air fractions of each snow layer. For freezing or frozen soils below the water table, diffusion is limited to the remaining liquid (CLM4 allows for some freezing point depression). The bottom boundary condition for all species is taken as a no-flux boundary. For unsaturated soils, Henry's law equilibrium is assumed at the interface with the water table.

For each time step, the net $\mathrm{CH}_{4}$ and $\mathrm{O}_{2}$ sinks in each model depth interval are computed. If the total demand for one of the species exceeds the amount available, the demand from each process associated with the sink is scaled by the fraction required to ensure non-negative concentrations. Since the methanotrophs are limited by both $\mathrm{CH}_{4}$ and $\mathrm{O}_{2}$, the stricter limitation is applied to methanotroph oxidation, and then the limitations are scaled back for other processes. Once these competitive interactions have been accounted for, Eq. (1) is solved using a Crank-Nicholson solver (Press et al., 1989) (Appendix A). Two methane balance checks are performed at each timestep to insure that the diffusion solution and the 
time-varying aggregation over inundated and non-inundated areas strictly conserves methane molecules (except for production minus consumption) and carbon atoms. We note that this solution method ignores the potentially large changes in simulated oxidation rates that might occur across the model time step (1800s) when large changes in $\mathrm{O}_{2}$ concentrations are simulated. However, addressing this problem would require an iterative solution that could substantially increase the simulation time for the $\mathrm{CH}_{4} \mathrm{BGC}$ model component.

\subsection{Inundated fraction prediction}

An important control on large-scale $\mathrm{CH}_{4}$ emission estimates is the simulated spatial extent of inundated area. Previous regional and global $\mathrm{CH}_{4}$ emission models have applied wetland distribution estimates from Matthews and Fung (1987) (e.g., Zhuang et al., 2004; Walter et al., 2001a; Cao et al., 1996), Landsat (Potter et al., 2006), or the IGBP soils database (Wania et al., 2010). However, these static distributions do not allow for prognostic analysis of changes in surface hydrology that may affect $\mathrm{CH}_{4}$ emissions over the 21 st century.

We therefore developed a simplified dynamic representation of spatial inundation based on recent work by Prigent et al. (2007), who described a multi-satellite approach to estimate the global monthly inundated fraction $\left(F_{\mathrm{i}}\right)$ over an equal area grid $\left(0.25^{\circ} \times 0.25^{\circ}\right.$ at the equator) from 1993 2000. They compared their estimates to the static estimates of Matthews and Fung (1987) and discussed the lack of sensitivity of their method to small fractional inundation (less than $\sim 10 \%$ cover). They suggested that the IGBP estimate for inundation could be used as a measure of sensitivity of their detection approach at low inundation (i.e., the satellite dataset may not represent small, isolated water bodies in areas that are otherwise largely unsaturated). To address this issue, we used the sum of their satellite-derived $F_{\mathrm{i}}$ and the constant IGBP estimate when it was less than $10 \%$ to parameterize an estimate of inundation in CLM4 (Eq. 11). A further complication in applying the satellite observations is that they provide an estimate of the inundated area, while the biogeochemical model requires an estimate of the saturated area, which may be missed in the absence of open water. We expect that ongoing work in the hydrology submodel of CLM4 will alleviate the need for this simplification in future model versions.

Currently in CLM4, an index of the saturated fraction $\left(f_{\mathrm{s}}\right)$ of a gridcell is computed from the simulated water table depth and a spatially variable parameter and is used in the model's estimate of surface runoff (Niu et al., 2005; Oleson et al., 2008). However, the simulated global $f_{\mathrm{s}}$ is substantially larger than the satellite inundation estimate and does not match the spatial or temporal patterns of variability. We therefore used a simple inversion for the inundated fraction for methane production $\left(f_{\mathrm{i}}\right)$ to optimize three parameters $\left(p_{1}, p_{2}, p_{3}\right)$ for each grid cell in a simple model based on simulated water table depth $\left(z_{\mathrm{w}}\right)$ and surface runoff $\left(Q_{\mathrm{r}}\right.$ $\left.\left(\mathrm{mm} \mathrm{s}^{-1}\right)\right)$ :

$f_{\mathrm{s}}=P_{1} e^{\frac{-z_{\mathrm{w}}}{p_{2}}}+p_{3} Q_{\mathrm{r}}$.

We note that many wetland systems are comprised of a series of hummocks and hollows at fine spatial scale (Whalen, 2005), and that the area described as inundated by the satellite reconstruction may consist of a patchwork of inundated and exposed surfaces. Given the complexities of characterizing these features globally, we did not attempt to include that level of complexity in this version of the model.

\subsection{Model spin-up and forcing}

We used a modified version of the standard method to spin up terrestrial $\mathrm{C}$ and $\mathrm{N}$ cycles in CLM4 (Thornton et al., 2007), which includes (1) a $500 \mathrm{yr}$ accelerated spin up phase using the atmospheric forcing dataset (Qian et al., 2006) provided with CLM4, continuously cycled over a 25 yr period (19481972); (2) an additional $1000 \mathrm{yr}$ spin up with land use, $\mathrm{N}$ deposition, and aerosol deposition set to 1850 levels; and (3) a transient simulation from 1850 to present accounting for changes in atmospheric $\mathrm{CO}_{2}, \mathrm{~N}$ deposition, aerosol deposition, and land use.

Though CLM4 includes changes that improve the simulation of permafrost dynamics (i.e., thermal and hydrologic properties of soil organic matter, Lawrence and Slater, 2008; $\sim 50 \mathrm{~m}$ deep ground column, Lawrence et al., 2008), these changes coupled with soil hydrology changes resulted in unrealistically dry active layers that can severely limit vegetation productivity (and consequently $\mathrm{CH}_{4}$ production) in permafrost zones (Lawrence et al., 2011). S. C. Swenson and D. L. Lawrence (personal communication, 2011) have alleviated the dry bias associated with frozen soils in CLM4 through the introduction of an ice impedance factor that reduces the hydraulic conductivity of frozen soils and a fibricto-sapric transition in peat thermal and hydraulic properties (Letts et al., 2000). These changes greatly increase the nearsurface soil moisture content in regions with seasonally and permanently frozen soil, consistent with observations (Hinzman et al., 1991). To make sure that plants in permafrost regions can access the increased near-surface soil moisture, we modified the calculation of the soil-moisture limitation on transpiration so that only unfrozen soil layers are considered.

\subsection{Site-level observations}

We compared model predictions to observations from 13 sites in the mid- to high-latitudes and 5 sites in the tropics (Table 3). We only provide here a brief description of the sites and observations since they are thoroughly described in the given citations and many of these datasets have been used and described by previous modeling groups to test their $\mathrm{CH}_{4}$ emission models. The comparison between predictions 
Table 3. Description of the sites and measurements used in the comparison with model predictions.

\begin{tabular}{|c|c|c|c|c|}
\hline Site \# & Site Location & Citation & Site Description & Measurement Method \\
\hline \multicolumn{5}{|c|}{ Extra-Tropics } \\
\hline 1 & Stordalen, Sweden & $\begin{array}{l}\text { Jackowicz-Korczynski } \\
\text { et al. (2010) }\end{array}$ & $\begin{array}{l}\text { Sub-Arctic mire. Grass and a } \\
\text { moss layer. }\end{array}$ & $\begin{array}{l}\text { Eddy-covariance flux tower, } \\
\text { half hourly }\end{array}$ \\
\hline 2 & Stordalen, Sweden & Svensson et al. (1999) & $\begin{array}{l}\text { Sub-Arctic mire. Data com- } \\
\text { bined for wet ombrotrophic, } \\
\text { wet intermediate ombro-mi- } \\
\text { nerotrophic, } \\
\text { and wet minerotrophic sites. }\end{array}$ & Static chamber \\
\hline 3 & Degerö, Sweden & Granberg et al. (2001) & $\begin{array}{l}\text { Oligotrophic lawn in a boreal } \\
\text { mire. }\end{array}$ & Static chamber \\
\hline 4 & Salmisuo, Finland & Saarnio et al. (1997) & $\begin{array}{l}\text { Minerogenic oligotrophic fen. } \\
\text { Grass, bog-rosemary, cran- } \\
\text { berry, sedge, and a moss layer. }\end{array}$ & Static chamber \\
\hline 5 & Alaska, USA & $\begin{array}{l}\text { Whalen and } \\
\text { Reeburgh (1992) }\end{array}$ & $\begin{array}{l}\text { Tundra underlain by per- } \\
\text { mafrost. Mosses with no } \\
\text { vascular plants. Mean of } \\
\text { tussock and inter-tussock } \\
\text { depressions. }\end{array}$ & Static chamber \\
\hline 6 & Boreas NSA-Fen, Canada & Bubier et al. (1998) & $\begin{array}{l}\text { Fen with peat and brown } \\
\text { mosses, bog-bean, sedges. }\end{array}$ & Static chamber \\
\hline 7 & Boreas SSA-Fen, Canada & Verma et al. (1998) & $\begin{array}{l}\text { Peatland. Poorly minerotro- } \\
\text { phic to oligotrophic. } \\
\text { Sphagnum and Scheuchzeria } \\
\text { palustris and Chamaedaphne } \\
\text { calculata }\end{array}$ & Eddy-covariance \\
\hline 8 & $\begin{array}{l}\text { Minnesota, USA, } \\
\text { Junction Fen }\end{array}$ & Dise (1993) & $\begin{array}{l}\text { Open poor fen dominated by } \\
\text { Carex oligosperma. }\end{array}$ & Static chamber \\
\hline 9 & Minnesota, USA & Clement et al. (1995) & $\begin{array}{l}\text { Transitional between poorly } \\
\text { minerotrophic fen and an olig- } \\
\text { otrophic bog. }\end{array}$ & $\begin{array}{l}\text { Static chamber and micro- } \\
\text { meteorological measurements }\end{array}$ \\
\hline 10 & Missisissippi, USA & Koh et al. (2009) & $\begin{array}{l}\text { Oaks, open floating vege- } \\
\text { tation, several herbaceous } \\
\text { species. Data combined from } \\
\text { the permanently and occasion- } \\
\text { ally flooded zones. }\end{array}$ & $\begin{array}{l}\text { Static chamber and micro- } \\
\text { meteorological measurements }\end{array}$ \\
\hline 11 & New Hampshire, USA & $\begin{array}{l}\text { P. M. Crill, personal } \\
\text { communication }(2010)\end{array}$ & Fen. & Static chamber \\
\hline 12 & $\begin{array}{l}\text { Michigan, USA, } \\
\text { Buck Hollow Bog }\end{array}$ & $\begin{array}{l}\text { Shannon and } \\
\text { White (1994) }\end{array}$ & $\begin{array}{l}\text { Bog. Ombrotrophic peatland. } \\
\text { Moss and rush. }\end{array}$ & Static chamber \\
\hline 13 & Ruoergai, China & Ding et al. (2004) & Freshwater marsh. Carex. & Static chamber \\
\hline \multicolumn{5}{|c|}{ Tropical } \\
\hline 14 & Panama & Keller (1990) & Tropical swamp. Palm. & Static chamber \\
\hline 15 & Central Amazonia, Brazil & Wassmann et al. (1992) & $\begin{array}{l}\text { Flooded forest. Pseudobo- } \\
\text { max munguba, Cratavea ben- } \\
\text { thamii, and Vitex cymosa. }\end{array}$ & \\
\hline 16 & Pantanal, Brazil & $\begin{array}{l}\text { Alavala and } \\
\text { Kirchoff (2000) }\end{array}$ & Tropical wetland. & Floating static chamber \\
\hline 17 & Orinoco, Venezuela & Smith et al. (2000) & Flooded forest, floodplain. & Floating static chamber \\
\hline 18 & Amazon River, Brazil & Devol et al. (1990) & $\begin{array}{l}\text { Floodplain of the Amazon } \\
\text { River main stem. Data for } \\
\text { flooded forests and macro- } \\
\text { phyte beds combined. }\end{array}$ & Floating static chamber \\
\hline
\end{tabular}


and observations was complicated because (1) directly measured climate forcing was unavailable at any of the sites; (2) we did not change the default model surface conditions (e.g., aerenchyma area, LAI) to be consistent with actual values at each site (this approach is consistent with that used in the Carbon-Land Model Intercomparison Project (CLAMP); Randerson et al., 2009); and (3) many of the sites have very sparse spatial and temporal data coverage.

\subsection{Global atmospheric inversions}

We compared the global CLM4Me $\mathrm{CH}_{4}$ emission estimates with results from three recent global atmospheric inversion estimates. The first inversion (Bergamaschi et al., 2009) used the Scanning Imaging Absorption Spectrometer for Atmospheric Chartography (SCIAMACHY) aboard the ENVISAT satellite and NOAA ship and aircraft profile samples to estimate wetland + rice $\mathrm{CH}_{4}$ emissions at $4^{\circ} \times 6^{\circ}$ globally, and also used the telescoping capability of the Match model to perform high-resolution $\left(1^{\circ} \times 1^{\circ}\right)$ inversions over selected regions for 2004. Their study also reported sensitivity to emission estimates by selectively including and excluding portions of the observations from the inversion. The second inversion (Bloom et al., 2010) used a combination of SCIAMACHY observations, simple $\mathrm{CH}_{4}$ emission estimates as priors, and estimates of inundation derived from the GRACE satellite to estimate $\mathrm{CH}_{4}$ emissions, and their uncertainty, globally at a resolution of $3^{\circ} \times 3^{\circ}$ for 2003-2005. The third inversion (Bousquet et al., 2006) applied the chemistry transport model LMDZ-INCA to infer $1^{\circ} \times 1^{\circ}$ global surface $\mathrm{CH}_{4}$ emissions between 1984 and 2003. We combined their estimates for swamps, bogs, tundra, rice, and soils for comparison to an annual mean and uncertainty range for CLM4Me simulations and each of the inversions based on combined spatial and temporal variability.

\subsection{Change in high latitude $\mathrm{CH}_{4}$ emissions over the next century}

In order to evaluate the effects of 21 st century climate change on high-latitude emissions and the uncertainty in those emissions caused by parameter uncertainty, we performed a 21st century RCP4.5 (Reference Concentration Pathway; $4.5 \mathrm{~W} \mathrm{~m}^{-2}$ ) scenario (Clarke et al., 2007). For this scenario, we first generated atmospheric forcing data from a fully coupled $1.9^{\circ} \times 2.5^{\circ} \mathrm{CCSM} 41850-2100$ historical and RCP4.5 simulation, using the default CCSM4 model (with none of the CLM4 modifications mentioned above). We then used the 1850-1874 atmospheric forcing to spin up the CLM4 model offline with our modifications for the methane model and the changes to Arctic hydrology, rooting depth, and peat properties (Sect. 2.3), using 1850 values for aerosol deposition, $\mathrm{N}$ deposition, $\mathrm{CO}_{2}$, and land use. Finally, we used the spin-up to initialize an offline 1850-2100 run with historical and RCP4.5 conditions for aerosol deposition, $\mathrm{N}$ deposition, $\mathrm{CO}_{2}$, and land use, forced by the data generated from the fully coupled 1850-2100 CCSM4 run. Since none of the methane model parameters as currently implemented affect the basic soil C-N cycle in CLM4, and since the methane and oxygen soil concentrations come to equilibrium in less than a month, we were able to replicate the parameter sensitivity experiments discussed above by repeating the 1995-1999 and 2095-2099 periods of this simulation for each sensitivity case.

We treated this experiment as a sensitivity study rather than a prediction because of the missing processes and model deficiencies discussed earlier. In particular, the lack of processes responsible for long-term carbon storage do not allow the model to generate the observed large stocks of highlatitude carbon, a problem exacerbated by the low highlatitude productivity in the fully coupled CCSM4 as compared to CLM4 forced offline by NCEP reanalysis data. However, it does allow us to estimate 21 st century highlatitude methane emissions in the absence of changes in highlatitude plant productivity, availability of permafrost $\mathrm{C}$, and thermokarst processes. We evaluated the change in $\mathrm{CH}_{4}$ emissions regionally as ratios between the means in 20902099 and 1990-1999, and related the differences to changes in $\mathrm{CH}_{4}$ production, $\mathrm{CH}_{4}$ oxidation, and inundation.

\subsection{Model sensitivity to parameter uncertainty}

As discussed above, many of the parameters used in regional and global $\mathrm{CH}_{4} \mathrm{BGC}$ models are highly uncertain. To illustrate the sensitivity of our $\mathrm{CH}_{4}$ emission predictions to parameter uncertainties, we varied several parameters in the model (Table 1): $Q_{10}$ of $\mathrm{CH}_{4}$ production $(1.5,3,4)$; factors used in predicting $\mathrm{CH}_{4}$ oxidation $\left(R_{\mathrm{o}, \max }, K_{\mathrm{CH}_{4}}\right.$, $K_{\mathrm{O}_{2}}$; factor of 10 above and below baseline); factors affecting aerenchyma transport $(20 \%$ and $200 \%$ of baseline aerenchyma area, non-grass aerenchyma porosity (17 and $33 \%$ of grass value)), the unsaturated zone $K_{\mathrm{CH}_{4}}$ and $R_{\mathrm{O} \text {, max }}$ (making them equivalent to the baseline wetland values), gas diffusivity multiplier (factor of 10 ), and $f_{\mathrm{pH}}$ and $f_{\mathrm{pE}}$ (include both $\mathrm{pH}$ and redox potential, ignore both $\mathrm{pH}$ and redox potential, and include $\mathrm{pH}$ and ignore redox potential). The high and low values for parameters were chosen based on a literature review.

As mentioned above, $Q_{10}$ values for $\mathrm{CH}_{4}$ production and consumption are uncertain, although it is likely that production is more temperature sensitive than oxidation when methanogens are not substrate-limited. To investigate how this asymmetry might manifest at large scales, we performed a series of sensitivity runs with production $Q_{10}$ values of 2 (baseline), 3, and 4 and oxidation values of 1.5, 1.9 (baseline), and 3. 

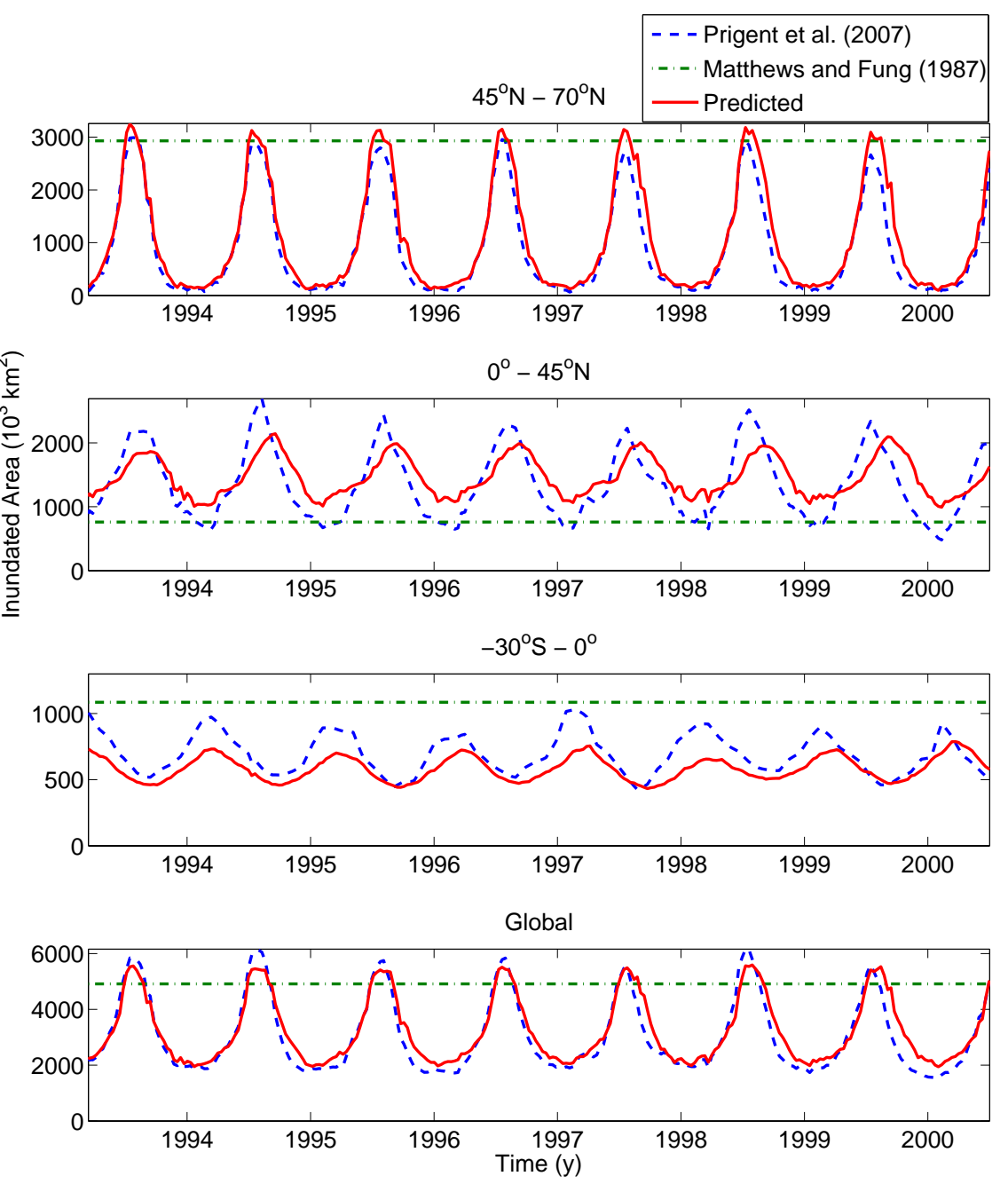

Fig. 2. $F_{\mathrm{i}}$ for three latitude bands and globally estimated from three approaches: satellite reconstruction (Prigent et al., 2007); the approach described in Matthews and Fung (1987), and the approach integrated in CLM4.

\section{Results}

\subsection{Prediction of inundated fraction}

CLM4Me predictions of inundated fraction $\left(F_{\mathrm{i}}\right)$ were consistent with the spatial and temporal patterns of the satellite reconstruction at large spatial scales (Fig. 2), although there were often discrepancies at the gridcell level. Between June and September, simulated $F_{\mathrm{i}}$ was over-estimated in northern Asia, and underestimated in mid- and eastern Canada, portions of northern Asia, and northern India (Fig. 3). The differences in Canada are likely affected by difficulties in predicting water table depth and overland flow in permafrost regions. The errors in India are potentially important for $\mathrm{CH}_{4}$ emission estimates, since this is a region where high $\mathrm{CH}_{4}$ emissions have been predicted by inversions (Bergamaschi et al., 2009; Bloom et al., 2010). The differences in this region may be related to rice irrigation, which CLM4 does not currently include. As mentioned earlier, ongoing work in CLM4 should allow us to update this representation of inundation with a more mechanistic model of surface hydrology in future model versions.

\subsection{Comparison to site-level observations}

We compared model predictions in the offline simulation forced by the meteorology dataset provided with CLM4 (Qian et al., 2006) against the $\mathrm{CH}_{4}$ emission observations described in Table 3 . We did not have directly measured climate forcing at any of the sites, nor did we change the default model surface conditions (e.g., aerenchyma area, LAI at $1.9^{\circ} \times 2.5^{\circ}$ resolution) to be consistent with actual values at each site. Thus, we expect some differences between measured and simulated $\mathrm{CH}_{4}$ emissions to result from differences between actual and imposed climate forcing and surface conditions. Using the central parameter values (Table 1), 


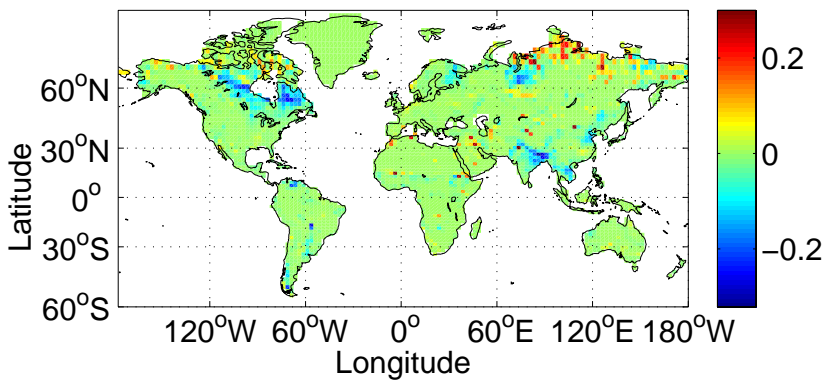

Fig. 3. Difference between mean June-September observed and simulated inundation.

simulated emissions matched the observed emissions relatively well at some of the sites (Fig. 4), while substantial differences in seasonality and magnitude existed at other sites. To emphasize the important role oxidation has in affecting the net surface flux, we also show the sum of the net simulated surface flux and column-integrated $\mathrm{CH}_{4}$ oxidation. Differences between the simulated and observed net $\mathrm{CH}_{4}$ emissions were large in several of the tropical sites, but we caution that very few observations were available to create the monthly averages shown. We note that Meng et al. (2011) used a version of CLM4Me to compare simulated and observed $\mathrm{CH}_{4}$ emissions in unsaturated tropical sites.

\subsection{Comparison to top-down $\mathrm{CH}_{4}$ flux estimates}

The patterns and magnitudes of simulated annual-average bottom-up and top-down (atmospheric inversion) $\mathrm{CH}_{4}$ fluxes are consistent across most of the $10^{\circ}$ latitude bands (Fig. 5). The largest differences between the baseline-parameter CLM4Me and inversion predictions were in the $20^{\circ} \mathrm{S}-10^{\circ} \mathrm{S}$, $40^{\circ} \mathrm{N}-50^{\circ} \mathrm{N}$, and $50^{\circ} \mathrm{N}-60^{\circ} \mathrm{N}$ latitude bands. The excessive production in the $20^{\circ} \mathrm{S}-10^{\circ} \mathrm{S}$ band (for the baseline parameter case) can be explained by the high CLM4 GPP bias in the Amazon (Beer et al., 2010). This comparison is crude, since the ranges on the bottom-up and top-down estimates span different time periods and spatial resolutions. However, the comparison does illustrate broadly consistent patterns in emissions by the different approaches and how individual model parameters can affect the simulated zonal $\mathrm{CH}_{4}$ emissions. For example, increasing the $\mathrm{CLM} 4 \mathrm{Me} \mathrm{CH}_{4}$ production $Q_{10}$ value from the baseline value of 2 to 3 decreased high latitude emissions to be closer to top-down inversion values, increased simulated $20^{\circ} \mathrm{S}-10^{\circ} \mathrm{S}$ net emissions to unrealistically high values, and increased $\mathrm{CH}_{4}$ fluxes between $10^{\circ} \mathrm{S}$ and $20^{\circ} \mathrm{N}$.

\subsection{Global $\mathrm{CH}_{4}$ emission estimates}

Using the baseline parameter set, CLM4Me estimated annual-average $\mathrm{CH}_{4}$ emissions over the 25 -yr simulation (Fig. 6) of 270, 160, 50, and $70 \mathrm{Tg} \mathrm{CH}_{4} \mathrm{yr}^{-1}$ globally, in the tropics, in the temperate zone, and north of $45^{\circ} \mathrm{N}$, re- spectively. These values are within the (wide) range reported from bottom-up and top-down inversion analyses (see Introduction). Because of the many interacting factors affecting net $\mathrm{CH}_{4}$ emissions, we found no simple relationship between annual gridcell $\mathrm{CH}_{4}$ emissions and either land area, inundated area, or NPP.

\subsection{Global uptake of atmospheric methane in unsaturated ecosystems}

Using estimates of tropospheric $\mathrm{OH}$ radical destruction and stratospheric photo-dissociation and the fact that methane is relatively well-mixed in the atmosphere, King (1997) estimated the global methane soil sink to be $\sim 40 \mathrm{Tg} \mathrm{CH}_{4} \mathrm{yr}^{-1}$, while the IPCC (2007; WG1 7.4.1.1) reported a range of 26-34 $\mathrm{Tg} \mathrm{CH}_{4} \mathrm{yr}^{-1}$ with a preferred value of $30 \mathrm{Tg} \mathrm{CH}_{4} \mathrm{yr}^{-1}$ (Snover and Quay, 2000). A modeling study by Ridgwell et al. (1999) simulated the sink to be $20-51 \mathrm{Tg} \mathrm{CH}_{4} \mathrm{yr}^{-1}$. We predicted a global $\mathrm{CH}_{4}$ sink of $31 \mathrm{Tg} \mathrm{CH}_{4} \mathrm{yr}^{-1}$ using the baseline parameter set for CLM4Me. We tested the sensitivity of this prediction to several scenarios: (a) setting upland oxidation parameters equal to those for wetlands, which caused a global change of less than $0.1 \mathrm{Tg} \mathrm{CH}_{4} \mathrm{yr}^{-1}$; (b) allowing production above the water table in anoxic microsites, which decreased the sink to $15 \mathrm{Tg} \mathrm{CH}_{4} \mathrm{yr}^{-1}$; (c) removing the low-moisture limitation of methane oxidation, which increased the sink to $38 \mathrm{Tg} \mathrm{CH}_{4} \mathrm{yr}^{-1}$; and (d) multiplying the gas diffusivity by 10 to mimic convective transport, which increased the sink to $80 \mathrm{Tg} \mathrm{CH}_{4} \mathrm{yr}^{-1}$.

\subsection{Effects of aerenchyma on net emissions}

We investigated the impact of aerenchyma area on net $\mathrm{CH}_{4}$ emissions in saturated and unsaturated conditions by forcing the specific aerenchyma area $T$ (Eq. 6) to vary based on a scaling factor $\left(f_{\mathrm{A}}\right)$. For illustration, we present the results for a 1-yr simulation at the Michigan, USA site (Table 3). In saturated conditions, the aerenchyma $\mathrm{CH}_{4}$ flux decreased as $f_{\mathrm{A}}$ increased, since the additional $\mathrm{O}_{2}$ increased $\mathrm{CH}_{4}$ oxidation in the rhizosphere (Fig. 7a). Note that to isolate the impact of changing aerenchyma area, we did not increase labile $\mathrm{C}$ inputs to the system as would likely occur in a real system if root area increased. The ebullition $\mathrm{CH}_{4}$ flux is largest in the absence of aerenchyma $\left(f_{\mathrm{A}}=0\right)$, and smallest under the default aerenchyma area (Fig. 7b). The net effect of increasing aerenchyma area from 0 to the default value is to reduce the net surface $\mathrm{CH}_{4}$ flux by $\sim 20 \%$ (Fig. $7 \mathrm{c}$ ). We also experimented with different approaches to characterizing ebullition transport (i.e., allowing equilibrium and disassociation of the bubbles as they travel up through the column), and allowing enhanced aqueous diffusion (which could result from convection in soil fluids) by increasing the diffusion coefficients by up to a factor of 10 , with qualitatively similar results. In unsaturated conditions with a prescribed water table depth of 

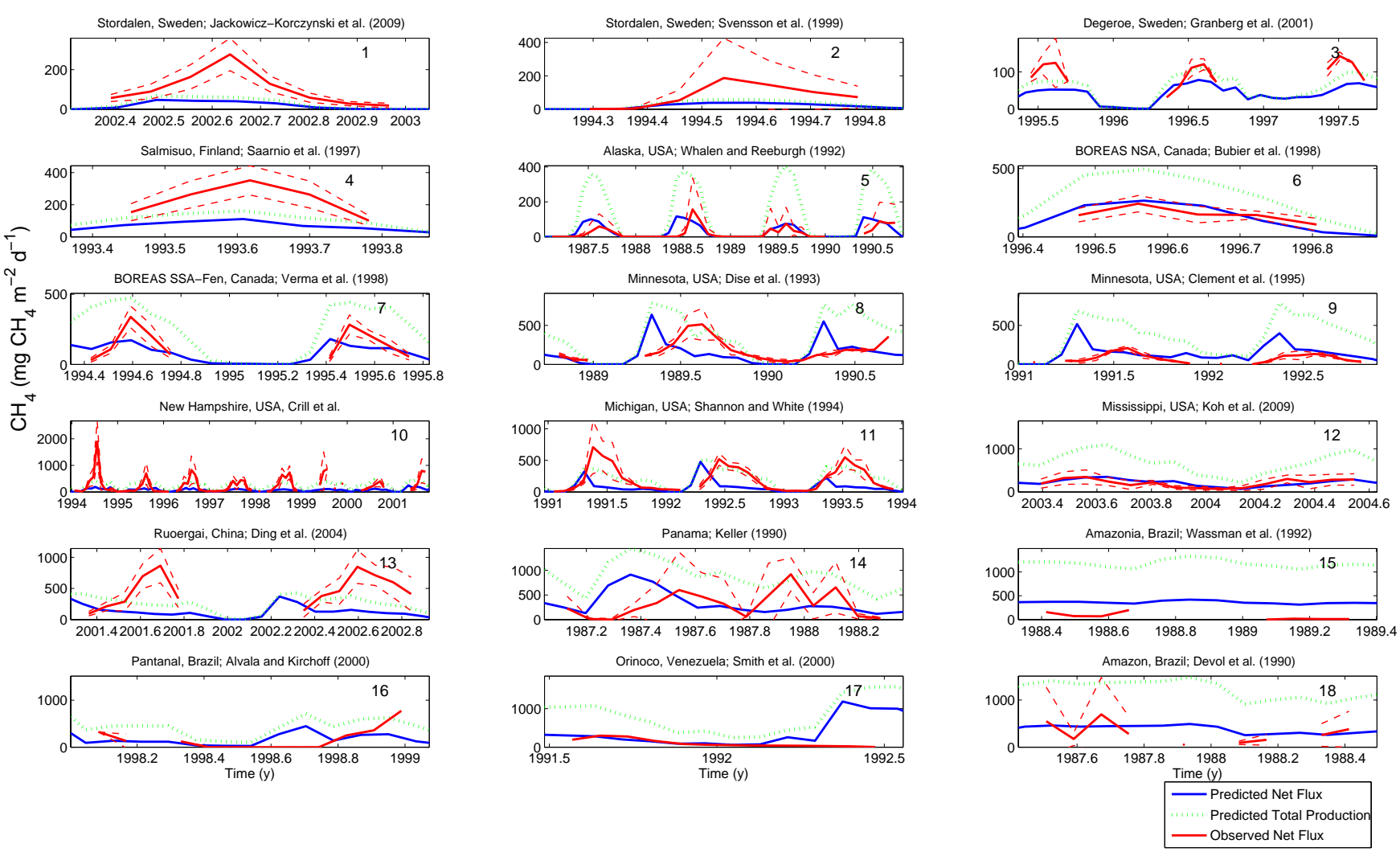

Fig. 4. Comparison between monthly-mean simulated net $\mathrm{CH}_{4}$ flux, simulated total $\mathrm{CH}_{4}$ production (i.e., net $\mathrm{CH}_{4}$ emission + oxidation), and observed net $\mathrm{CH}_{4}$ flux (1 standard deviation bounds are shown as dashed lines). Citations for the datasets are given in title of each subplot and Table 3.

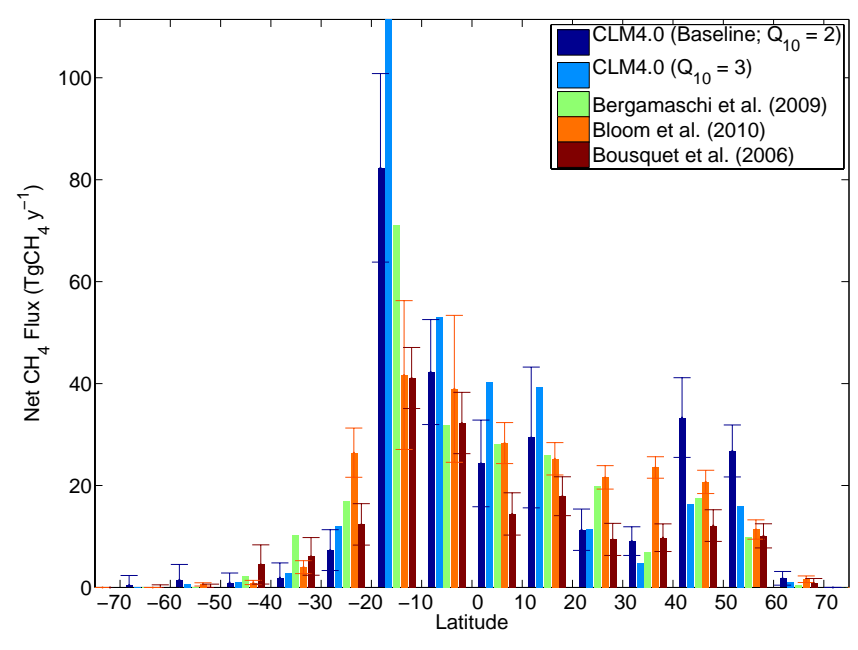

Fig. 5. Comparison between average-annual $\mathrm{CH}_{4}$ estimates from CLM4Me with baseline parameters, CLM4Me with baseline parameters except $Q_{10}=3$, and three atmospheric inversions (Bloom et al., 2010; Bergamaschi et al., 2009; Bousquet et al., 2006) for $10^{\circ}$ latitude bands.

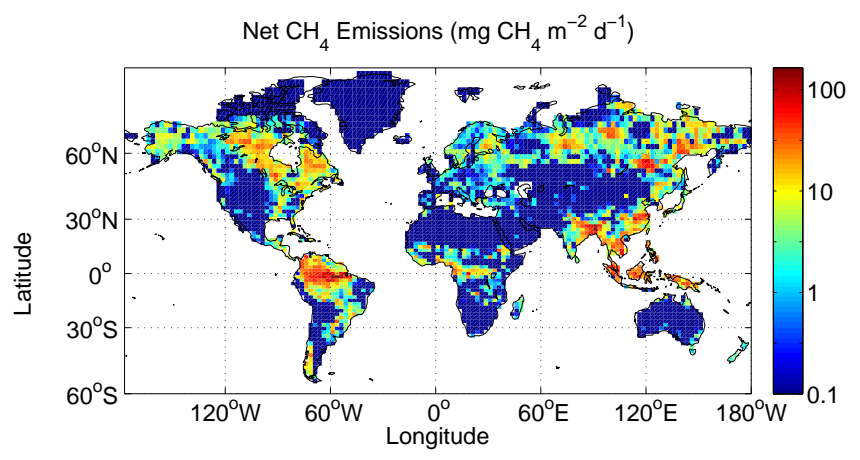

Fig. 6. Annual-average $\mathrm{CH}_{4}$ emissions over the 25-yr simulation. The fluxes are shown on a logarithmic color scale, and truncated to be above $0.1 \mathrm{mg} \mathrm{CH}_{4} \mathrm{~m}^{-2} \mathrm{~d}^{-1}$, to illustrate the large spatial heterogeneity in simulated fluxes.

$17 \mathrm{~cm}$ in the same gridcell, the simulated net $\mathrm{CH}_{4}$ flux did not decrease with increasing aerenchyma area.

As described earlier, most previous $\mathrm{CH}_{4}$ models have assumed a fixed fraction of $\mathrm{CH}_{4}$ is oxidized in aerenchyma, whereas CLM4Me prognoses the oxidation based on demands from all $\mathrm{O}_{2}$ consumers. To predict the fraction of 

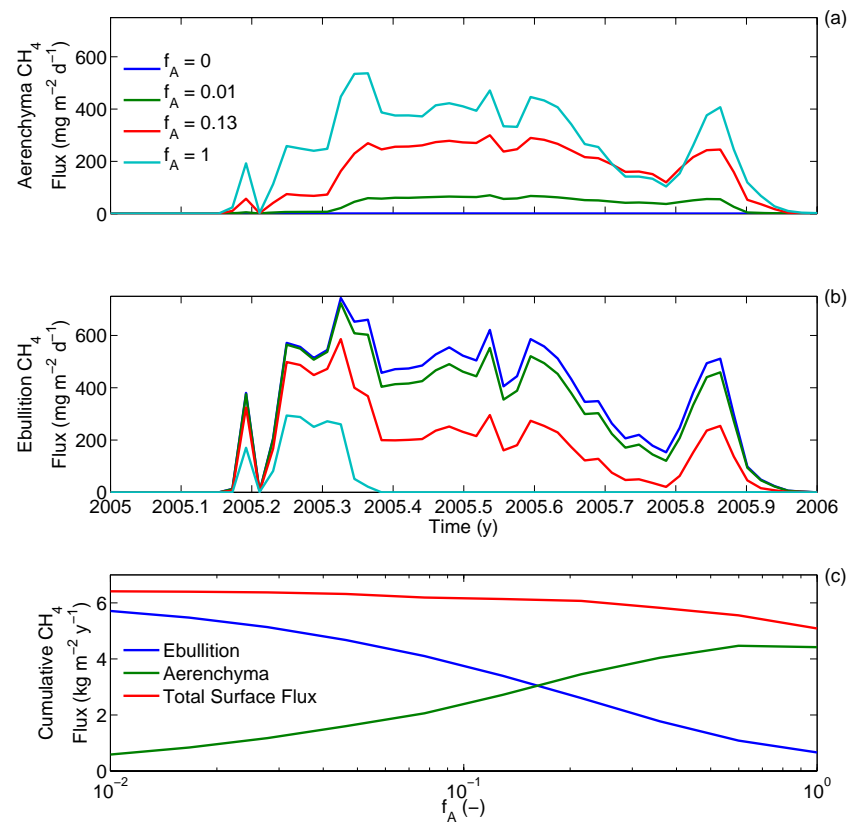

Fig. 7. (a) Predicted aerenchyma, (b) ebullition, and (c) cumulative $\mathrm{CH}_{4}$ fluxes as a function of the fraction $\left(f_{\mathrm{A}}\right)$ of total aerenchyma specific area for a gridcell corresponding to the Minnesota, USA site.

$\mathrm{CH}_{4}$ oxidized, we compared the default simulation with one that excluded aerenchyma oxidation and $\mathrm{O}_{2}$ diffusion. Globally, CLM4Me estimated an oxidized fraction of $\sim 0.6$ in aerenchyma; this fraction was spatially (Fig. 8) and temporally heterogeneous. The oxidation-to-production ratio varied seasonally and with latitude. For example, north of $45^{\circ} \mathrm{N}$, the fraction of produced $\mathrm{CH}_{4}$ that was oxidized before it reached the soil surface varied between 0.35 and 0.75 , with a minimum in April-May and maximum in SeptemberOctober. In the tropics, this fraction varied between 0.5 and 0.7 , with a minimum in May and maximum in July-August.

\subsection{Effect of allowing emission via transpired dissolved methane}

CLM4Me predicts $\mathrm{CH}_{4}$ emissions via the transpiration stream. This approach may overestimate the actual transpired flux, because it assumes that no methanotrophs are active in plant tissue. Considering all the sensitivity scenarios, including allowing production in anoxic microsites above the water table, $\mathrm{CH}_{4}$ emissions via this mechanism were less than $1 \mathrm{TgCH}_{4} \mathrm{yr}^{-1}$. We conclude that $\mathrm{CH}_{4}$ emissions via transport in the transpiration stream are unlikely to significantly contribute to the global methane budget.

\subsection{1st century $\mathrm{CH}_{4}$ emissions scenario}

We used the baseline model structure and parameterization to evaluate differences in predicted $\mathrm{CH}_{4}$ emissions between

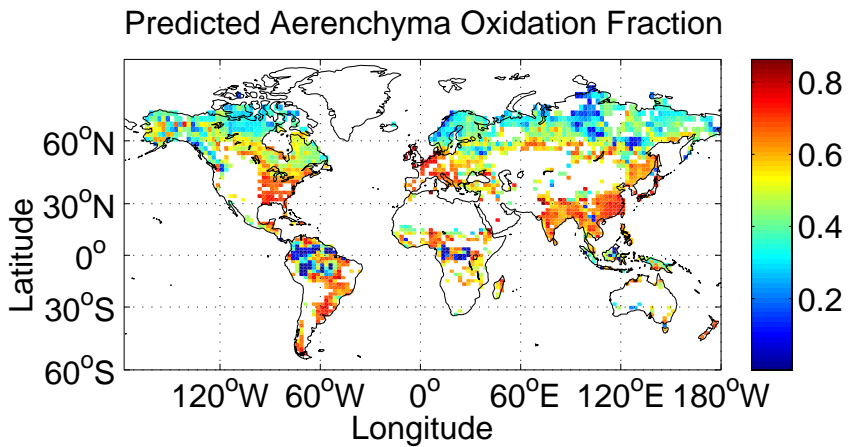

Fig. 8. Simulated fraction of annual $\mathrm{CH}_{4}$ oxidized in rhizosphere; the global flux-weighted average is 0.6. For clarity, only gridcells with annual-average $\mathrm{CH}_{4}$ emissions greater than $0.1 \mathrm{mg} \mathrm{CH}_{4} \mathrm{~m}^{-2} \mathrm{~d}^{-1}$ are shown.

2090-2099 and 1990-1999. CLM4Me predicted 20\% increases in $\mathrm{CH}_{4}$ emissions globally, in the Tropics, at midlatitudes, and at high-latitudes. At mid- and high-latitudes, increases in $\mathrm{CH}_{4}$ emissions were concurrent with comparable increases in $\mathrm{CH}_{4}$ production and oxidation and $\sim 10 \%$ increases in NPP. However, high-latitude fractional inundation decreased by about $20 \%$, while mid-latitude inundated area remained approximately unchanged. Increases in predicted tropical $\mathrm{CH}_{4}$ fluxes resulted from a combination of increased $\mathrm{CH}_{4}$ production (which increased $\sim 15 \%$ ) and increased inundated area (which increased $\sim 10 \%$ ). The sensitivity of future $\mathrm{CH}_{4}$ emissions to parameter uncertainty was comparable to the sensitivity of present emissions, except for the temperature sensitivity to production. In our baseline scenario, we assumed that methanogenesis was primarily substrate-limited with a default methane production $Q_{10}$ of 2, slightly higher than the CLM4 soil decomposition $Q_{10}$ of 1.5. Assuming methanogenesis has a $Q_{10}$ of 4 results in predicted high-latitude $\mathrm{CH}_{4}$ flux increases over the 21st century of about $50 \%$.

These large-scale averages are complicated to interpret because they subsume substantial spatial heterogeneity. For example, predicted $\mathrm{CH}_{4}$ emissions increased in about a $10^{\circ}$ zone surrounding Hudson's bay (with increases in inundation and $\mathrm{CH}_{4}$ production and oxidation), but decreased over much of the continuous permafrost portions of Alaska (because of decreases in inundation and relatively larger increases in oxidation compared to production). Portions of northern Europe had increases in predicted $\mathrm{CH}_{4}$ emissions despite concurrent decreases in inundated area. In the currently discontinuous permafrost areas of northern Asia, $\mathrm{CH}_{4}$ emissions increased because of increases in inundated area. However, predicted $\mathrm{CH}_{4}$ emissions decreased in the currently continuous permafrost areas of northern Asia, due to reductions in inundated area and increases in oxidation larger than increases in production. 


\subsection{Sensitivity of simulated $\mathrm{CH}_{4}$ emissions to parameter uncertainty}

We performed model simulations to characterize the sensitivity of site-level, high-latitude, and tropical $\mathrm{CH}_{4}$ fluxes to variations in several model parameters using reasonable ranges distilled from the literature. Of the parameters tested, those associated with the temperature dependence of $\mathrm{CH}_{4}$ production, potential $\mathrm{CH}_{4}$ oxidation rate, and aerenchyma area had the largest effects (up to a factor of four in annual $\mathrm{CH}_{4}$ emissions) in the large-scale sensitivities (Fig. 9). The sensitivity of simulated monthly $\mathrm{CH}_{4}$ emissions at the site level was often substantially greater than for the largescale means. For example, at the Minnesota sites, variation in $R_{0 \text {, max }}$ affected net August $\mathrm{CH}_{4}$ surface fluxes by more than a factor of ten.

We also tested how differences in the temperature sensitivity of $\mathrm{CH}_{4}$ production and oxidation $\left(Q_{10}\right)$ affected $\mathrm{CH}_{4}$ emissions (not shown). The relative responses were different between high latitudes and the Tropics. For example, for the baseline oxidation $Q_{10}$ of 1.9 , high-latitude $\mathrm{CH}_{4}$ emissions decreased by more than a factor of two as the production $Q_{10}$ increased; the opposite pattern was simulated for the Tropics. An oxidation $Q_{10}$ of 3 led to more than a factor of 2 reduction in high-latitude $\mathrm{CH}_{4}$ emissions for all values of production $Q_{10}$ tested.

We performed a sensitivity analysis to the inclusion of a simple mechanism for simulating methane emissions during fall freeze-up. We found that this extended the season of large high-latitude emissions a few days longer into the fall, and increased total high latitude fluxes by $3 \%$. However, most of the extra emissions were via aerenchyma in inundated areas, which may not be realistic. Emissions actually decreased slightly in non-inundated areas due to increased oxidation during the spring thaw.

As a final sensitivity analysis, we allowed $\mathrm{CH}_{4}$ production above the water table in anoxic microsites, which increased simulated global methane fluxes by $21 \%$. Due to the high ratio of global surface unsaturated to saturated area, the methane production nearly doubled, though most of this additional production was oxidized before reaching the surface. We caution, however, that this result assumes our baseline parameters for oxidation kinetics, and that the generally large sensitivity of net fluxes to oxidation kinetics would likely be enhanced with this large amount of additional $\mathrm{CH}_{4}$ production.

\section{Discussion}

\subsection{Inundated fraction}

Errors in the simulated fractional inundation of a particular gridcell are of first order importance to gridcell $\mathrm{CH}_{4}$ estimates, yet regional and global models poorly represent the

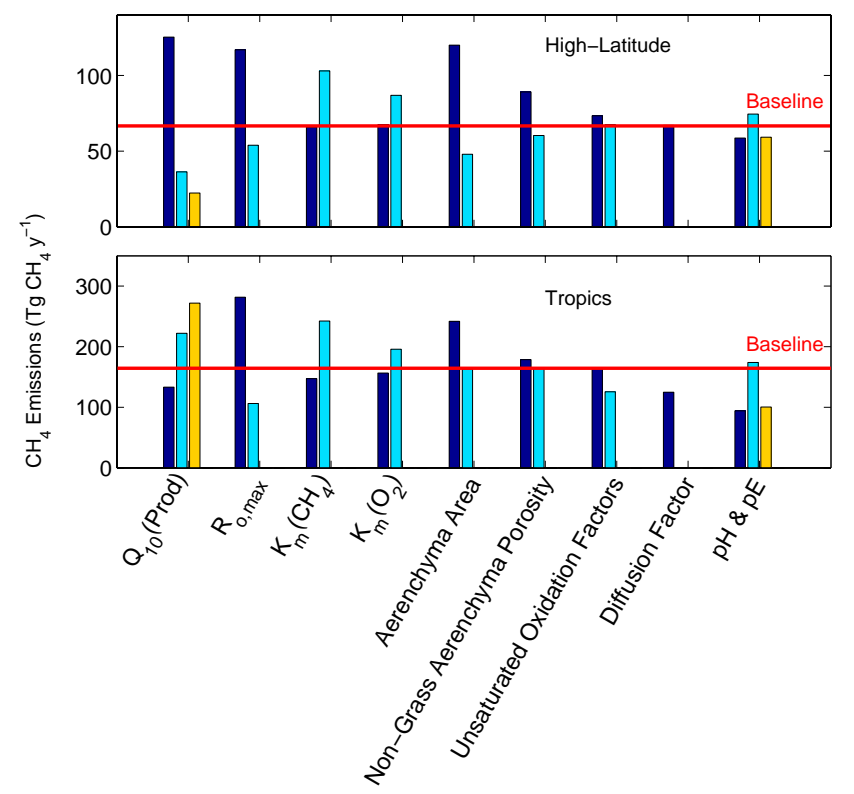

Fig. 9. Single value sensitivity analysis around the baseline set of values for $Q_{10}$ of production $(1.5,3,4)$; inundated oxidation parameters $\left(R_{\mathrm{O}, \max }\right)\left(1.25 \times 10^{-6}, 1.25 \times 10^{-4}\right) ; K_{\mathrm{CH}_{4}}\left(5 \times 10^{-4}\right.$, $\left.5 \times 10^{-2}\right) ; K_{\mathrm{O}_{2}}\left(2 \times 10^{-3}, 2 \times 10^{-1}\right)$; aerenchyma area $(0.2,2)$; aerenchyma non-grass porosity $(0.05,0.15)$; unsaturated oxidation factors ( $R_{\mathrm{O} \text {,max }}$ and $\mathrm{K}_{\mathrm{CH}_{4}}$ set to be the same as saturated values), soil diffusivity (increase by a factor of 10 ), and $\mathrm{pH}$ and $\mathrm{pE}$ effects $\left(f_{\mathrm{pH}}\right.$ and $f_{\mathrm{pE}}$ applied, $f_{\mathrm{pH}}$ and $f_{\mathrm{pE}}$ set to $1, f_{\mathrm{pH}}$ applied and $f_{\mathrm{pE}}$ set to 1$)$. See Methods for description of parameter values used.

processes resulting in small-scale and seasonal inundation. Many of the ecosystems responsible for $\mathrm{CH}_{4}$ emissions, such as bogs and fens, occur at spatial scales well below those resolved in GCMs. Although the Prigent et al. (2007) satellite reconstruction gives a good first estimate of global inundation, more work is required to address uncertainties associated with small water bodies and to test the approach against site-level observations. Further, our approach for integrating the satellite reconstruction into CLM4Me's $F_{\mathrm{i}}$ estimate is dependent on simulated seasonal variability of water table depth and surface runoff, both of which are difficult to predict globally. We expect that ongoing work in the hydrology submodel of CLM4, using fine-scale topographical information and including the unique hydrology of peatlands, will alleviate the need for this simplification in future model versions.

\subsection{Simulated and observed $\mathrm{CH}_{4}$ emissions}

Comparing simulated land-surface emissions from a global model to site-level observations is problematic for many reasons, and particularly for $\mathrm{CH}_{4}$ emissions because of the episodic and spatially heterogeneous nature of the fluxes. Most empirical $\mathrm{CH}_{4}$ emission estimates from terrestrial systems have been made with surface flux chambers with relatively long intervals between sampling compared to the 
characteristic time of variability in the fluxes (Table 3). For example, all of the observations available to us from the Tropics were from relatively infrequently sampled flux chambers. Several recent studies outside of the Tropics have reported $\mathrm{CH}_{4}$ emissions using eddy covariance systems. These systems can sample a larger area at higher frequency than can flux chambers, but come with their own suite of complications with respect to comparison to simulated fluxes. For example, the footprint associated with the flux measurement depends on wind direction and speed, atmospheric boundary layer properties (e.g., depth, stability), and surface roughness. Improvements in $\mathrm{CH}_{4}$ biogeochemical modeling will benefit from estimates of spatial scaling associated with flux chamber measurements, relationships between spatially-integrated fluxes derived from flux chambers and properly footprint-weighted eddy covariance flux measurements, and perhaps larger-scale surface flux estimates inferred from top-down inversions using local and satellitederived atmospheric concentration observations.

A further complexity in interpreting differences between simulated and observed $\mathrm{CH}_{4}$ fluxes arises because our predictions used global gridded inputs, rather than from a simulation where the model is forced with specific site information and meteorology. As a result, the land-surface properties and meteorological forcing will be different than those existing at the site. These inconsistencies result, at least partially, from the relatively coarse resolution of the simulation gridcells compared to the scale of spatial heterogeneity in many systems.

Simulated $\mathrm{CH}_{4}$ emissions depend on several model predictions outside of the $\mathrm{CH}_{4}$ biogeochemical model, including NPP, heterotrophic respiration, soil hydrology, and soil temperature. Because simulated belowground respiration serves as the driver of $\mathrm{CH}_{4}$ production in the model, errors in NPP propagate to errors in $\mathrm{CH}_{4}$ production. To illustrate the extent to which errors in NPP may be contributing to errors in CLM4Me's $\mathrm{CH}_{4}$ flux estimates, we compared CLM4 and MODIS-derived NPP estimates at the four Swedish and Finnish sites (Fig. 4). Three issues are relevant in this comparison: (1) how well CLM4 matched the gridcell MODIS NPP estimate; (2) how well the MODIS gridcell $\left(1.89^{\circ} \times 2.5^{\circ}\right)$ average NPP represents the specific site NPP $(1 \times 1 \mathrm{~km})$; and (3) how accurate the MODIS-derived NPP estimates are for these wetland systems.

With respect to the first point, CLM4's and the equivalent $1.89^{\circ} \times 2.5^{\circ}$ MODIS NPP estimates matched relatively well for the magnitude and seasonality at the two Stordalen sites, relatively well for the magnitude but not the seasonality at Degerö, and neither magnitude not seasonality at Salmisuo (Fig. 10). Regarding the second point, differences between the gridcell-average CLM4 and $1 \mathrm{~km}$ MODIS pixel corresponding to the individual wetland sites are large, with a factor of 2 to 3 low bias in the predictions in growing-season cumulative NPP for the Degerö and two Stordalen sites. If we assume that simulated $\mathrm{CH}_{4}$ emissions increase with NPP, holding all other ecosystem characteristics constant (perhaps supra-linearly, since oxidative capacity may saturate), then bringing CLM4's NPP estimates closer to the MODIS estimate would bring $\mathrm{CH}_{4}$ predictions closer to the site-level observations for the Degerö and two Stordalen sites. This simple analysis highlights the broader point that spatial heterogeneity in land-cover and vegetation type is often large at typical GCM-scale resolution. This problem is particularly acute when predicting methane fluxes from inundated systems that are often comprised of small inter-connected water bodies, or with variations in micro-topography that can lead to small-scale variations in inundation.

It is common practice (as was done here) to test $\mathrm{CH}_{4}$ biogeochemistry models by comparing net $\mathrm{CH}_{4}$ emission predictions and observations. However, because the net $\mathrm{CH}_{4}$ emission is often small compared to the gross production and oxidation fluxes, it is relatively easy to tune the models to match observations at a single site, particularly since the flux measurements are often sparse in time. We contend that even a relatively successful comparison between simulated and observed net $\mathrm{CH}_{4}$ fluxes cannot be considered a reliable indication that the model is correctly simulating the underlying mechanisms (for which simultaneous measurements for testing are rarely available) that will determine the future response of the system. Properly testing the model requires observations that constrain the gross fluxes, transport, and the relevant forcing variables. For example, in the current structure of many GCM-scale $\mathrm{CH}_{4}$ models, testing the $\mathrm{CH}_{4}$ production representation would require observations to constrain methanogenesis substrate production; ratio of $\mathrm{CH}_{4}$ to $\mathrm{CO}_{2}$ production; and temperature, $\mathrm{pH}$, and redox potential dependencies (Eq. 2). Testing the $\mathrm{CH}_{4}$ oxidation representation would require observations that constrain the kinetics (Eq.7); $\mathrm{O}_{2}$ levels in soil water and the rhizosphere; competition for $\mathrm{O}_{2}$; and temperature, $\mathrm{pH}$, and redox potential dependencies. Testing simulated transport would require observations of ebullition; aerenchyma properties, pressure gradients, and $\mathrm{CH}_{4}$ and $\mathrm{O}_{2}$ concentrations; and soil $\mathrm{CH}_{4}$ concentrations. Even a subset of these observations could be helpful in evaluating model fidelity. However, because these types of model evaluations are rarely performed (primarily because of a lack of data), simulations of $\mathrm{CH}_{4}$ emissions under different environmental forcing, including future climate conditions, must be considered relatively uncertain.

\subsection{Comparison to atmospheric inversions}

The patterns of CLM4Me-simulated and atmosphericinversion $\mathrm{CH}_{4}$ emissions across latitude bands were broadly consistent with the baseline parameter set (Fig. 5). Although this agreement is encouraging, our sensitivity analysis argues that uncertainty in the bottom-up predictions is very large. We expect considerable levels of uncertainty also exist in the inversion emissions; estimates of this uncertainty were not available for this comparison, except for the Bloom et 

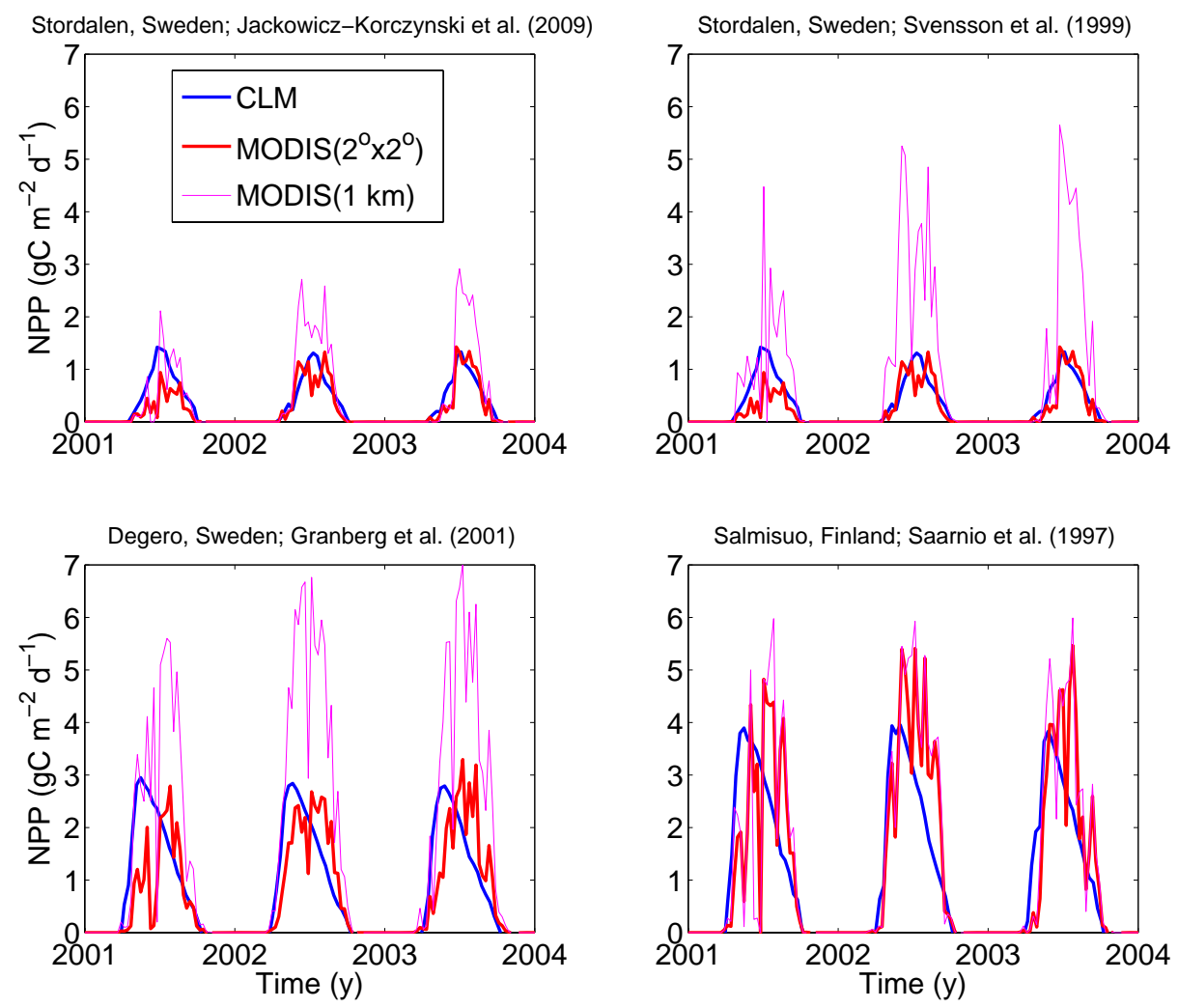

Fig. 10. NPP estimates from CLM $4,2^{\circ} \times 2^{\circ}$ MODIS, and the MODIS $1 \mathrm{~km}$ gridcell corresponding to the site.

al. (2010) study (error bars on the other inversions in Fig. 6 represent the standard deviation of annual fluxes across each inversion analysis period). The atmospheric inversions for wetlands and rice emissions depend on a number of relatively uncertain inputs, including atmospheric transport fields, $\mathrm{CH}_{4}$ observations, prior estimates of $\mathrm{CH}_{4}$ emissions, estimates of inundated fraction, estimates of other $\mathrm{CH}_{4}$ sources, and atmospheric hydroxyl radical chemistry. A valuable next step could be to use a relatively mechanistic global $\mathrm{CH}_{4}$ biogeochemical model (e.g., CLM4Me, TEM, LPJ-WhyMe) to generate more accurate prior estimates for the inversions. The inversions could be used to improve constraints on a few of the bottom-up model parameters known to have large impacts on simulated net $\mathrm{CH}_{4}$ fluxes, such as those determining the fraction of produced $\mathrm{CH}_{4}$ that is oxidized before entering the atmosphere.

\subsection{1st century $\mathrm{CH}_{4}$ emissions scenario}

Our predicted increases in global $\mathrm{CH}_{4}$ emissions of about $20 \%$ are smaller than estimates from the studies mentioned in the Introduction (Zhuang et al., 2006; Gedney et al., 2004; Bohn et al., 2007; Shindell et al., 2004), perhaps because these studies (1) did not include the potential for the inundated fraction to decrease because of enhanced drainage through thawing permafrost and (2) applied rela- tively high long-term methane production temperature sensitivities. While current model predictions must be considered too uncertain to be treated as an accurate prediction of future emissions (for the reasons described above), there are things to be learned by comparing future model scenarios. For example, our prediction that spatially variable changes in inundation will occur, and that these changes will impact $\mathrm{CH}_{4}$ emissions, may be a more robust prediction.

\subsection{Sensitivity and uncertainty analysis}

Several previous analyses have examined sensitivity of simulated $\mathrm{CH}_{4}$ emissions to variations in individual model parameters (e.g., Petrescu et al., 2010; Walter et al., 2001a; Wania et al., 2010). Van Huissteden et al. (2009) applied the GLUE (Generalized Likelyhood Uncertainty Estimation) methodology (Lamb et al., 1998) to characterize uncertainty using a modified version of the Walter et al. (2001b) model. They concluded that the model is most sensitive to the temperature dependence of microbial processes and parameters affecting $\mathrm{CH}_{4}$ transport and oxidation in vegetation, consistent with our analysis (Fig. 6).

Below we discuss the sensitivity of simulated $\mathrm{CH}_{4}$ emissions to temperature, aerenchyma properties, $\mathrm{pH}$, redox potential, and temperature sensitivity of production and oxidation. We note that this type of parameter sensitivity analysis 
cannot test the importance of processes missing from the models (e.g., thermokarst), errors in characterizing system properties (e.g., $\mathrm{pH}$ and redox potential), and realistic treatment of wetland vegetation.

\subsubsection{Temperature}

The overall temperature sensitivity of net $\mathrm{CH}_{4}$ emissions is the result of the temperature sensitivity of the component processes of primary productivity, production of methanogenesis substrate from soil and litter organic matter, methanogenesis, $\mathrm{CH}_{4}$ methanotrophy, and transport. As a result, predicting future climate feedbacks from terrestrial $\mathrm{CH}_{4}$ emissions is difficult. In the following paragraphs we discuss the dominant controlling temperature sensitivities, how they may evolve as climate changes, and some of the simplifications current models use and the potential biases that may result.

Increased temperatures may increase NPP, particularly in high-latitude systems currently limited by growing season length or nutrient availability. The strength of this temperature sensitivity will vary between different ecosystems, depending on vegetation type and changes in precipitation and hydrology. Increasing temperatures may also increase the stock of decomposable soil organic matter by thawing permafrost.

Soil organic matter decomposition will likely increase as temperatures increase, perhaps faster than NPP, at least in the short term (Friedlingstein et al., 2006). Moreover, anaerobic decomposers may have higher temperature sensitivity than aerobic decomposers, in which case large increases in additional substrate for methanogenesis could be produced in the short term, although over decades carbon stocks may become more depleted.

Methanogenesis seems to have an especially high sensitivity to temperature (Segers, 1998; Walter and Heimann, 2000; Zhuang et al., 2004; Lloyd and Taylor, 1994). Segers (1998) synthesized methane production from 1046 laboratory experiments using soils from a range of wetland types; the $Q_{10}$ of all samples together was $4.1( \pm 0.4)$. He also reported that, in previous incubation experiments, $Q_{10}$ for methane production ranged from 1.5 to 28 . This wide range was explained in some studies (but not all) by interactions with alternative electron acceptor reduction or substrate availability, which may have co-varied with temperature. Further, the baseline temperature used in the $Q_{10}$ formulation likely varies spatially, since microbes can adapt to their local climatic conditions. The hypothesized reason for acetogenotrophic methanogenesis having higher temperature sensitivity than fermenters or aerobic decomposers is that acetogenotrophic methanogenesis is barely enthalpically favorable, so the primary Gibbs free energy release comes from the increase in entropy associated with the disintegration of acetate into two gas molecules (one $\mathrm{CH}_{4}$ and one $\mathrm{CO}_{2}$ ). In any case, this temperature sensitivity will not be relevant for net $\mathrm{CH}_{4}$ emis- sions unless ample substrate is available for methanogenesis, while a number of studies (Bergman et al., 1998; Basiliko et al., 2007) and one review (Whalen, 2005) suggest that high-latitude methanogenesis is primarily substrate limited, and accelerating decomposition under increased temperatures could cause depletion of substrate for methanogenesis.

Rates of methanogenesis under increased temperatures also depend on the availability of alternative electron acceptors. If these acceptors are input to wetland systems at constant rates (e.g., from parent material) and therefore do not match increases in substrate supply, they may become relatively depleted and methanogenesis may increase. In contrast, if these acceptors increase in supply with temperature (e.g., $\mathrm{NO}_{3}^{-}$from mineralization), then methanogenesis may not increase. This relationship assumes that there is a small range of redox potential in which methanogenesis and alternative electron acceptor reduction both occur. However, if there is a larger range of redox potential in which these two processes compete, it is possible that increased temperatures could favor methanogenesis. Experiments should address this question.

Methanotrophy is often limited by methane and oxygen diffusion rates rather than kinetics (Smith et al., 2003), and does not have as high temperature sensitivity as methanogenesis (Segers, 1998; Whalen, 2005). Transport of methane and oxygen are only weakly sensitive to temperature, with the exception of ebullition: increased temperatures will decrease the solubility of methane and oxygen. Consequently, oxidation may not increase as quickly as methane production, or may even decrease with increased temperature due to increased ebullition, so increasing temperatures may increase the proportion of methane produced that escapes oxidation.

Existing models that simplify this complex set of processes, including ours, may yield erroneous predictions of methane feedbacks to climate change. For instance, many models predict methane production based on prescribing a ratio of $\mathrm{CH}_{4}$ production to $\mathrm{CO}_{2}$ production or to NPP, both of which depend on temperature. In some cases, the temperature sensitivity of methanogenesis alone is assumed to be a proxy for the temperature sensitivity of this ratio, causing a large increase in high latitude methane emissions to be predicted as temperatures increase. However, methanogenesis is only one step in the sequence of processes discussed above, and is not generally the rate-limiting step. Increased temperatures may increase $\mathrm{C}$ mineralization rates (including methane production) in the short term but may eventually deplete soil organic matter stocks. In this case, net methane emissions will only be higher than at present if temperature increases also increase the ratio of methane production to overall $\mathrm{C}$ mineralization, or the proportion of methane escaping oxidation. Accurate prediction of changes in net methane fluxes as temperatures increase thus requires a detailed process model resolving each of the individual processes described above. 
As an example of how these mechanisms interact, we focused on the overall temperature sensitivity of $\mathrm{CH}_{4}$ production and oxidation by varying each across a relatively small range (2-4) compared to values used in previous modeling studies (Sect. 2.7). CLM4Me simulated large differences in $\mathrm{CH}_{4}$ emissions for these ranges of values (more than a factor of 2 regionally and up to a factor of 5 at individual gridcells). Typically, a baseline temperature is also set which does not vary with spatial location, ecosystem type, or time. This assumption is likely incorrect, as microbes can acclimate and evolve to their environment (e.g., pH, temperature, substrate availability, $\mathrm{CH}_{4}$ and $\mathrm{O}_{2}$ levels). Work to better characterize the environmental controls on these processes, and how they may change as climate changes, would reduce overall uncertainties in $\mathrm{CH}_{4}$ emission predictions.

\subsection{2 $\mathrm{pH}$ and redox potential}

Many of the current GCM-scale $\mathrm{CH}_{4}$ models apply a single optimum $\mathrm{pH}$ value across gridcells to methanogenesis and to methanotrophy. However, there is evidence for variability in the influence of $\mathrm{pH}$ on methanogenesis (Whalen, 2005). As reviewed by Le Mer and Roger (2001), methanotrophs tolerate a larger $\mathrm{pH}$ range than methanogens, with some peat soils exhibiting $\mathrm{CH}_{4}$ consumption at $\mathrm{pH}<4$.7. The choice of a single optimum $\mathrm{pH}$ and functional form for these processes may lead to incorrect estimates of the impact of changes in $\mathrm{pH}$ on net $\mathrm{CH}_{4}$ emissions.

Our and previous models have attempted to account for both $\mathrm{pH}$ and redox using a product of individual factors (Eq. 2), even though an interaction term is likely required. Because of this interaction, significant error may exist in parameters that are generated from field data where only one (e.g., $f_{\mathrm{pH}}$ ) was measured. For example, rain-fed bogs, especially those with plants producing acidic litter like Sphagnum, may simultaneously have substantial $\mathrm{CH}_{4}$ emissions and lower $\mathrm{pH}$ and redox potential than groundwater-fed fens because the bogs have lower replenishment rates of dissolved solutes (buffers or alternative electron acceptors).

Beyond the uncertainties in microbial response to $\mathrm{pH}$ and redox potential, an important complication relevant to regional- and global-scale models like CLM4Me is that aqueous concentrations of alternative electron acceptors and $\mathrm{pH}$ are difficult to predict because they are affected by a variety of factors, including inputs via surface and subsurface flow and atmospheric deposition, mineral soil and parent material, vegetation, and the activity of other microbial populations. In the global baseline CLM4Me simulations presented here, we did not include the effects of $\mathrm{pH}$ or redox potential (except for the effect of redox potential in seasonally inundated systems), since both their global distribution and impacts on $\mathrm{CH}_{4}$ production and oxidation are quite uncertain. The effects of $\mathrm{pH}$ and redox potential on net fluxes were tested in the sensitivity analysis, and resulted in less than a $20 \%$ change at high latitudes and about a factor of two change in net $\mathrm{CH}_{4}$ emissions in the Tropics (Fig. 6). Meng et al. (2011), using a different version of CLM4Me, performed a detailed analysis at several tropical sites of the effects of $\mathrm{pH}$ and redox potential on $\mathrm{CH}_{4}$ emissions.

\subsubsection{Aerenchyma impacts on net $\mathrm{CH}_{4}$ emissions}

Roots containing aerenchyma affect net $\mathrm{CH}_{4}$ emissions via three mechanisms: (1) as a conduit for $\mathrm{CH}_{4}$ transport (diffusive or advective) to the atmosphere which bypasses oxic soil; (2) as a conduit for $\mathrm{O}_{2}$ transport to the rhizosphere, which can enhance oxidation; and (3) as a source of rootcarbon substrate for methanogenesis. These three mechanisms, their interactions, and the density of aerenchyma across ecosystems are poorly characterized in the field and models, yet they strongly affect simulated $\mathrm{CH}_{4}$ emissions. For example, in our study, increasing aerenchyma area in unsaturated permafrost regions resulted in predictions of increased $\mathrm{CH}_{4}$ emissions through aerenchyma, because the perched water table led to areas where the water table was near, but not at, the surface. The net effect of aerenchyma was small in the unsaturated Tropics where the water table is generally simulated to be more than two meters below the surface. Increasing aerenchyma area lowered simulated $\mathrm{CH}_{4}$ emissions from the saturated high-latitudes and Tropics because more $\mathrm{O}_{2}$ diffused into the column, leading to increased methanotrophy. Thus, variation in aerenchyma properties and mechanisms can lead to different effects on net $\mathrm{CH}_{4}$ emissions in different systems and under different hydrological regimes. Using aerenchyma parameterizations appropriate for trees might lead to lower aerenchyma area and $\mathrm{CH}_{4}$ oxidation in inundated systems.

Many field studies have concluded that the presence of vascular plants with aerenchyma leads to increased net $\mathrm{CH}_{4}$ emissions (Morrissey et al., 1993; Schimel, 1995; Chanton et al., 1993; Bartlett et al., 1992; Frenzel and Karofeld, 2000; Grunfeld and Brix, 1999; Torn and Chapin, 1993) by providing an efficient escape mechanism for $\mathrm{CH}_{4}$. However, in large-scale $\mathrm{CH}_{4}$ biogeochemical models, separate representations of aerenchyma area (and the attendant diffusive pathway) and methanogenesis substrate inputs are required. In this context, interpreting these previous experimental manipulations as altering net $\mathrm{CH}_{4}$ emissions through changing aerenchyma area alone may be misleading, for several reasons. First, increasing any root area, including aerenchyma area, is likely associated with increased $\mathrm{C}$ supply to methanogens through exudation, root mortality, and root sloughing. Separating the effects of increased diffusive $\mathrm{CH}_{4}$ transport and $\mathrm{CH}_{4}$ production is difficult in field experiments. Second, increased aerenchyma area could reduce the aqueous $\mathrm{CH}_{4}$ concentration near the rhizosphere (through methanotrophy and reduced $\mathrm{CH}_{4}$ production), leading to smaller ebullition fluxes. However, ebullition is notoriously difficult to measure because it is sporadic and spatially heterogeneous, and is often underestimated. 
Four further complications exist regarding our ability to mechanistically model the effects of aerenchyma on $\mathrm{CH}_{4}$ emissions: (1) the location of the water table relative to the aerenchyma exit points; (2) the role of ventilation and advective transport in aerenchyma; (3) uncertainty in the model oxidation parameters; and (4) competition for $\mathrm{O}_{2}$ in the rhizosphere. Regarding the first point, Zona et al. (2009), using a large-scale water-table manipulation, observed that once the water table rose above the base of the plant (carex) stems, $\mathrm{CH}_{4}$ emissions decreased. They concluded that this seemingly contradictory effect might have occurred because the water covered the exit pathways of the aerenchymous tissues.

Second, as discussed in Methods, CLM4Me, and most other $\mathrm{CH}_{4}$ models of its class, do not represent the active ventilation processes used by some plants to bring oxygen into the roots or advective flow resulting from pressure gradients across the aerenchyma. The large number and variety of processes responsible for active $\mathrm{CH}_{4}$ and $\mathrm{O}_{2}$ transport in aerenchyma, and their differences across plant species (Ding and Cai, 2007), are daunting to consider including in global models like CLM4. Therefore, the development of simplified representations of these processes is an important area for future research.

Third, the oxidation kinetic parameters used in current $\mathrm{CH}_{4}$ biogeochemistry models are poorly constrained. For example, near-complete or near-zero $\mathrm{CH}_{4}$ oxidation can be predicted using oxidation kinetic parameters within the literature-reported range. Using the baseline parameter set described in Methods, we estimated that $\sim 60 \%$ of globally produced $\mathrm{CH}_{4}$ that would have escaped via aerenchyma is instead oxidized in the rhizosphere, with large spatial heterogeneity (Fig. 8), temporal heterogeneity, and sensitivity to oxidation and aerenchyma parameters (not shown). In contrast, the fraction of methane being oxidized in the rhizosphere has typically been set to a fixed parameter globally in previous models (e.g., $40 \%$ and $50 \%$ in Zhuang et al., 2004 and Wania et al., 2010, respectively).

Fourth, competition in the rhizosphere for $\mathrm{O}_{2}$ between methanotrophs, heterotrophs, root (i.e., autotrophic) respiration, and aqueous and aerenchyma transport impacts the fraction of produced $\mathrm{CH}_{4}$ emitted to the atmosphere. However, in the spatially complex environment of the rhizosphere, this competition may be controlled by transport (e.g., autotrophic respiration may have better access to $\mathrm{O}_{2}$ than methanotrophs) (Segers and Leffelaar, 2001a, b; Segers et al., 2001) and differences in population dynamics and environmental sensitivities (Whalen, 2005). To explore how these interactions impact simulated net $\mathrm{CH}_{4}$ emissions, we changed the competitive structure in CLM4Me so that when overall $\mathrm{O}_{2}$ demand exceeds supply, autotrophic respiration received twice the $\mathrm{O}_{2}$ it would have received with the default proportional competition structure (up to its total demand). This change led to $5 \%$ and $6 \%$ increases in high-latitude and tropical fluxes, respectively, because of the reduced $\mathrm{CH}_{4}$ oxidation by methanotrophs. Because this competition had a relatively small im- pact on net $\mathrm{CH}_{4}$ emissions at the regional scale, our assumption of proportional competition appears to be reasonable.

\subsection{Future model improvement}

A number of the deficiencies in CLM4Me and other models of its class would benefit from further observational, experimental, and modeling work. With respect to model structure improvements, the lack of a separate $\mathrm{C}$ cycle submodel for wetlands is a key limitation. The current use of the grid cell $\mathrm{C}$ cycle model may capture the broad dynamics of $\mathrm{C}$ fluxes through the system, but misses important differences in wetlands, such as the different vegetation characteristics, and $\mathrm{C}$ turnover responses to anaerobicity. Vertical resolution in soil $\mathrm{C}$ turnover and root exudation needs to be implemented in the model. In particular, root exudation and soil $\mathrm{C}$ at depth (particularly in permafrost zones) may have different responses to transient warming than the CLM4 heterotrophic respiration currently used to drive the $\mathrm{CH}_{4}$ model. The transient response of $\mathrm{CH}_{4}$ emissions to climate warming may also be biased by the low soil C stocks in CLM4, perhaps due to unrealistic treatment of long-term $\mathrm{C}$ storage in some areas critical to $\mathrm{CH}_{4}$ emissions. We are currently working to address these issues. Our use of the satellite reconstruction for fractional inundation is also an obvious area for model improvement, preferably by improvements to CLM4's surface and groundwater hydrology submodels.

There are two classes of observational and experimental studies that would benefit large-scale $\mathrm{CH}_{4}$ biogeochemical modeling: (1) those to improve the spatial representation of surface properties that affect $\mathrm{CH}_{4}$ emissions and (2) those to better constrain model structure and parameterization of processes. Of the first class, the most important results would be improved representation of (1) fractional inundation; (2) $\mathrm{pH}$ and redox potential in wetland systems; and (3) vegetation characteristics, such as aerenchyma area. Developing a process-level representation of $\mathrm{pH}$ and redox potential for global models is a substantial task, even if observations were available to specify the required inputs (e.g., $\mathrm{N}$ and alkalinity flows, $\mathrm{N}$ and $\mathrm{S}$ deposition, soil properties). An intermediate solution would be to use a spatially explicit global map of wetland types and distribution (e.g., Lehner and Doll, 2004) linked to estimates of $\mathrm{pH}$ and redox potential for each type. However, such an approach would not allow for dynamic changes that can occur over years to decades in these properties.

Examples of the second class of studies include site or laboratory experiments to better describe (1) the influence of environmental conditions such as temperature, substrate availability, $\mathrm{pH}$, and redox potential on $\mathrm{CH}_{4}$ oxidation and on all stages of $\mathrm{CH}_{4}$ production and (2) rhizosphere competition for $\mathrm{CH}_{4}$ and $\mathrm{O}_{2}$. Field experiments manipulating ecosystem temperature, substrate availability, and soil chemistry for at least several seasons would be especially valuable in isolating the separate influences of controlling variables and their 
interactions, and distinguishing between short-term transient behavior and equilibrium behavior. Such experiments could be especially valuable if they were specifically designed to improve parameterizations and mechanisms within the structures incorporated in current global $\mathrm{CH}_{4}$ biogeochemical models.

\section{Conclusions}

We integrated a $\mathrm{CH}_{4}$ biogeochemistry submodel (CLM4Me) into CLM4/CESM1 that includes representations of $\mathrm{CH}_{4}$ production, oxidation, aerenchyma transport, ebullition, aqueous and gaseous diffusion, and fractional inundation. We predicted very large sensitivities (up to a factor of 4 and 10 at the regional and gridcell scales, respectively) in $\mathrm{CH}_{4}$ fluxes from changes in model parameters consistent with values determined from laboratory and site-level measurements. The temperature dependence of $\mathrm{CH}_{4}$ productivity, potential $\mathrm{CH}_{4}$ oxidation rate, and aerenchyma area were dominant parameters affecting regional and global $\mathrm{CH}_{4}$ emissions. In the model, about $60 \%$ of global terrestrial $\mathrm{CH}_{4}$ production was oxidized before emission (net emissions are the difference between $707 \mathrm{Tg} \mathrm{CH}_{4} \mathrm{yr}^{-1}$ production and $433 \mathrm{Tg} \mathrm{CH}_{4} \mathrm{yr}^{-1}$ oxidation). These large gross fluxes create the potential for large inter-annual and decadal variability in net $\mathrm{CH}_{4}$ emissions if production and oxidation respond differently to environmental conditions. Further, because the net $\mathrm{CH}_{4}$ emissions are a relatively small fraction of the gross fluxes, errors in either gross flux can lead to relatively larger errors in simulated $\mathrm{CH}_{4}$ emissions.

In CLM4Me, sensitivity of $\mathrm{CH}_{4}$ emissions to aerenchyma area (alone, i.e., with constant root $\mathrm{C}$ input) is negative in saturated systems; the response of unsaturated systems depends on the water table depth. Aqueous transport of $\mathrm{CH}_{4}$ in the transpiration stream was predicted to be very small and could not explain recent claims of a large-scale aerobic $\mathrm{CH}_{4}$ source.

In a hypothetical future warming scenario (RCP4.5), CLM4Me predicted large declines in inundated area in continuous permafrost areas. Combined with a relatively low (compared to previous models) methanogenesis temperature sensitivity, we predicted a $\sim 20 \%$ increase (relatively lower than previous model estimates) in end-of-century highlatitude $\mathrm{CH}_{4}$ emissions. However, given model uncertainties and missing processes (e.g., permafrost dynamics), we ascribe low confidence to the current suite of predictions of future terrestrial $\mathrm{CH}_{4}$ feedback strength.

\section{Appendix A}

\section{Numerical solution to reaction and diffusion equation}

\section{A1 Crank-Nicholson solution to Eq. (1)}

The fully explicit decomposition of Eq. (1) can be written as

$$
\begin{gathered}
\frac{R_{j}^{n+1} C_{j}^{n+1}-R_{j}^{n} C_{j}^{n}}{\Delta t}=\frac{1}{\Delta x_{j}}\left[\frac{D_{p 1}^{n}}{\Delta x_{p 1}}\left(C_{j+1}^{n}-C_{j}^{n}\right)\right. \\
\left.-\frac{D_{m 1}^{n}}{\Delta x_{m 1}}\left(C_{j}^{n}-C_{j-1}^{n}\right)\right]+S_{j}^{n},
\end{gathered}
$$

where $j$ refers to the cell in the vertically discretized soil column (increasing downward), $n$ refers to the current time step, $\Delta t$ is the time step (s), $p 1$ is $j+1 / 2, m 1$ is $j-1 / 2$, and $S_{j}^{n}$ is the net source at time step $n$ and position $j$, i.e., $S_{j}^{n}=P(j, n)-E(j, n)-A(j, n)-O(j, n)$. The diffusivity coefficients are calculated as harmonic means of values from the adjacent cells. Equation (A1) is solved for gaseous and aqueous concentrations above and below the water table, respectively. The $R$ term ensures the total mass balance in both phases is properly accounted for. An analogous relationship can be generated for the fully implicit case by replacing $\mathrm{n}$ by $n+1$ on the $C$ and $S$ terms of Eq. (A1). Using an average of the fully implicit and fully explicit relationships gives:

$$
\begin{aligned}
& -\frac{1}{2 \Delta x_{j}} \frac{D_{m 1}}{\Delta x_{m 1}} C_{j-1}^{n+1}+\left[\frac{R_{j}^{n+1}}{\Delta t}+\frac{1}{2 \Delta x_{j}}\left(\frac{D_{p 1}}{\Delta x_{p 1}}+\frac{D_{m 1}}{\Delta x_{m 1}}\right)\right] \\
& C_{j}^{n+1}-\frac{1}{2 \Delta x_{j}} \frac{D_{p 1}}{\Delta x_{p 1}} C_{j+1}^{n+1}=\frac{R_{j}^{n}}{\Delta t}+\frac{1}{2 \Delta x_{j}}\left[\frac{D_{p 1}}{\Delta x_{p 1}}\left(C_{j+1}^{n}-C_{j}^{n}\right)\right. \\
& \left.-\frac{D_{m 1}}{\Delta x_{m 1}}\left(C_{j}^{n}-C_{j-1}^{n}\right)\right]+\frac{1}{2}\left[S_{j}^{n}+S_{j}^{n+1}\right]
\end{aligned}
$$

Equation (A2) is solved in CLM4Me with a standard tridiagonal solver, i.e.:

$a C_{j-1}^{n+1}+b C_{j}^{n+1}+c C_{j+1}^{n+1}=r$,

with coefficients specified in Eq. (A2).

\section{A2 Top boundary condition}

We assume the surface flux is $w\left(C_{1}^{n}-C_{\mathrm{a}}\right)$ and $w\left(C_{1}^{n+1}-C_{\mathrm{a}}\right)$ for the fully explicit and fully implicit cases, respectively, and $w$ is the surface boundary layer conductance as calculated in the surface latent heat calculations. If the top layer is not fully saturated, the $\frac{D_{m 1}}{\Delta x_{m 1}}$ term is replaced with a series combination: $\left[\frac{1}{w}+\frac{\Delta x_{1}}{D_{1}}\right]^{-1}$, and if the top layer is saturated, this term is replaced with $\left[\frac{K_{\mathrm{H}}}{w}+\frac{\Delta x_{1}}{D_{1}}\right]^{-1}$, where $K_{\mathrm{H}}$ is the Henry's law equilibrium constant. 


\section{A3 Interface between water table and unsaturated zone}

We assume Henry's Law equilibrium at the interface between the saturated and unsaturated zone and constant flux from the soil element below the interface to the center of the soil element above the interface. In this case, the coefficients are the same as described in Eq. (A2) and Sect. 6.2, except for the soil element above the interface:

$$
\begin{aligned}
& \frac{D_{p 1}}{\Delta x_{p 1}}=\left[K_{\mathrm{H}} \frac{\Delta x_{j}}{2 D_{j}}+\frac{\Delta x_{j+1}}{2 D_{j+1}}\right]^{-1} \\
& b=\left[\frac{R_{j}^{n+1}}{\Delta t}+\frac{1}{2 \Delta x_{j}}\left(K_{\mathrm{H}} \frac{D_{p 1}}{\Delta x_{p 1}}+\frac{D_{m 1}}{\Delta x_{m 1}}\right)\right] \\
& r=\frac{R_{j}^{n}}{\Delta t} C_{j}^{n}+\frac{1}{2 \Delta x_{j}}\left[\frac{D_{p 1}}{\Delta x_{p 1}}\left(C_{j+1}^{n}-K_{\mathrm{H}} C_{j}^{n}\right)\right. \\
& \left.-\frac{D_{m 1}}{\Delta x_{m 1}}\left(C_{j}^{n}-C_{j-1}^{n}\right)\right]+\frac{1}{2}\left[S_{j}^{n}+S_{j}^{n+1}\right]
\end{aligned}
$$

and the soil element below the interface:

$$
\begin{aligned}
& \frac{D_{m 1}}{\Delta x_{m} 1}=\left[K_{\mathrm{H}} \frac{\Delta x_{j-1}}{2 D_{j-1}}+\frac{\Delta x_{j}}{2 D_{j}}\right]^{-1} \\
& a=-K_{\mathrm{H}} \frac{1}{2 \Delta x_{j}} \frac{D_{m 1}}{\Delta x_{m 1}} \\
& r=\frac{R_{j}^{n}}{\Delta t}+C_{j}^{n}+\frac{1}{2 \Delta x_{j}}\left[\frac{D_{p 1}}{\Delta x_{p 1}}\left(C_{j+1}^{n}-C_{j}^{n}\right)\right. \\
& \left.\quad-\frac{D_{m 1}}{\Delta x_{m 1}}\left(C_{j}^{n}-K_{\mathrm{H}} C_{j-1}^{n}\right)\right]+\frac{1}{2}\left[S_{j}^{n}+S_{j}^{n+1}\right]
\end{aligned}
$$

\section{A4 Bottom boundary condition}

We assume a zero flux gradient at the bottom of the soil column.

\section{Appendix B}

\section{Seasonal inundation effects}

Predicting $\mathrm{CH}_{4}$ fluxes in a seasonally inundated system is an example of a general problem in GCM-scale land-surface models, i.e., that gridcell state variables are represented by a single mean value, when often there are important non-linear dependencies. We discuss our approach to approximating the effects of seasonal inundation in Methods, where we introduce a simplification (Eq. 3) to a more general solution that requires simulating an array of carbon states representing all fractions of the gridcell with unique annual inundation cycles. Consider a gridcell with constant annual temperature, constant rate of soil $\mathrm{C}$ input $(I)$, no low-moisture limitation on decomposition, and turnover time of the SOM stock $\tau$ in the absence of anoxia. When inundated, the soil decomposition turnover time increases by the factor $1 / \beta$. The mass

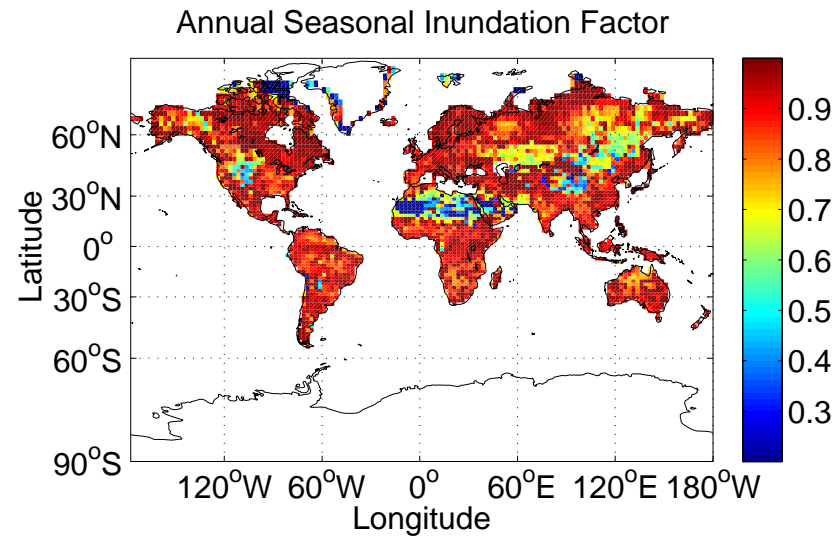

Fig. B1. $\mathrm{CH}_{4}$ flux-weighted, annual seasonal inundation factor (Eqs. 2 and 3). The global average is 0.95 .

balance equation for the idealized soil carbon stock, $C(x, t)$, is:

$\frac{d C(x, t)}{d t}=I-\frac{C(x, t)}{\tau}[\theta(x, t) \beta+(1-\theta(x, t))]$,

where $\theta=1$ for $x \leq f(t) ; \theta=0$ for $x>f(t)$; and the virtual dimension $x(\in[0,1])$ orders the fraction of the year during which individual sub-gridcell areas are inundated $(\phi(x))$, such that for all times $\theta\left(x_{2}\right) \leq \theta\left(x_{1}\right)$ for $x_{2}>x_{1} ; f$ is the fraction of the gridcell that is inundated, and $t$ is time. To compute the equilibrium stock, $\bar{C}(x)$, assume that the annual cycle of $f$ is constant and $\tau \gg 1$ yr. Then, integrating Eq. (B1) over an annual cycle $(\Delta t)$ yields

$$
\begin{aligned}
\int_{t}^{t+}+\Delta \mathrm{t} & \frac{d C\left(x, t^{\prime}\right)}{d t^{\prime}} d t^{\prime}=C(x, t+\Delta t)-C(x, t) \\
& =\int_{t}^{t+\Delta t}\left\{I-\frac{C\left(x, t^{\prime}\right)}{\tau}\left[\theta\left(x, t^{\prime}\right) \beta+\left(1-\theta\left(x, t^{\prime}\right)\right)\right]\right\} d t^{\prime} \\
& =I \Delta t-\Delta t \frac{\bar{C}(x)}{\tau}[\phi(x) \beta+(1-\phi(x))]
\end{aligned}
$$

The equilibrium stock is:

$\bar{C}(x)=\frac{I \tau}{\phi(x) \beta+(1-\phi(x))}=\frac{\bar{C}_{x>u}}{\phi(x) \beta+(1-\phi(x))}$,

where the interval $x>u$ corresponds to the continuously uninundated portion of the gridcell (if it exists).

To calculate the $\mathrm{CH}_{4}$ production, $P(t)$, suppose that all $\mathrm{CH}_{4}$ production comes from the instantaneously inundated fraction of the gridcell:

$d P(x, t)=f_{\mathrm{CH}_{4}} \beta \frac{\bar{C}(x)}{\tau} \theta(x, t) d x$.

To calculate production at time $t$, we substitute Eq. (B3) to Eq. (B4) and integrate from $x=0$ to $x=1$, which is equivalent to integrating from $x=0$ to $x=f(t)$ :

$P(t)=I \beta f_{\mathrm{CH}_{4}} \int_{0}^{f(t)} \frac{1}{\phi(x) \beta+(1-\phi(x))} d x$.

We calculated the production for several simple cases, such as a gridcell with inundation $A+\varepsilon$ for half the year and $A-\varepsilon$ 
for half the year, and found that the simplified expression in Eq. (3) was approximately correct. Equation (3) is exact for a gridcell that has an inundation $A$ for nearly the whole year but $A+\varepsilon$ for a short time period. As implemented in CLM4Me, the annual average of $f$ is weighted by the simulated instantaneous oxygen-unlimited heterotrophic respiration, to better accommodate non-constant temperature and low-moisture controls on decomposition and transient $\mathrm{C}$ inputs, unlike our simplifications in the explicit case above.

The annual-average seasonal inundation factor simulated by our simplified expression, weighted by methane production, has substantial heterogeneity (Fig. B1); the global average is 0.95 .

Acknowledgements. This work was supported by the Director, Office of Science, Office of Biological and Environmental Research, Climate and Environmental Science Division, of the US Department of Energy under Contract No. DE-AC02-05CH11231 to Berkeley Lab. Author contributions: Z. M. S. and W. J. R. developed CLM4Me and performed simulations and analysis; W. J. R. and M. S. T. designed the project; S. C. S. and D. M. L. developed the improvements to frozen soil hydrology and peat physical properties for CLM4; L. M., N. M., and P. H. developed the redox and $\mathrm{pH}$ factors; all authors contributed intellectually to the work.

Edited by: U. Seibt

\section{References}

Alavala, P. C. and Kirchoff, V. W. J. H.: Methane fluxes from the Pantanal floodplain in Brazil: Seasonal variation, in: $\mathrm{Non}-\mathrm{CO}_{2}$ Greenhouse Gases: Scientific understanding, control and implementation, edited by: Goossens, A., De Visscher, A., Boeckx, P., and Van Cleemput, O., Kluwer Academic Publishers, Netherlands, 95-99, 2000.

Anisimov, O. A., Lobanov, V. A., Reneva, S. A., Shiklomanov, N. I., Zhang, T. J., and Nelson, F. E.: Uncertainties in gridded air temperature fields and effects on predictive active layer modeling, J. Geophys. Res.-Earth, 112(12), F02s14, doi:10.1029/2006jf000593, 2007.

Arah, J. R. M. and Vinten, A. J. A.: Simplified Models of Anoxia and Denitrification in Aggregated and Simple-Structured Soils, Eur. J. Soil Sci., 46, 507-517, 1995.

Arah, J. R. M. and Stephen, K. D.: A model of the processes leading to methane emission from peatland, Atmos. Environ., 32, 32573264, 1998.

Armstrong, W.: Aeration in higher plants, Adv. Bot. Res., 7, 225332, 1979.

Baird, A. J., Beckwith, C. W., Waldron, S., and Waddington, J. M.: Ebullition of methane-containing gas bubbles from nearsurface Sphagnum peat, Geophys. Res. Lett., 31, L21505, doi:10.1029/2004g1021157, 2004.

Bartlett, K. B., Crill, P. M., Sass, R. L., Harriss, R. C., and Dise, N. B.: Methane Emissions from Tundra Environments in the YukonKuskokwim Delta, Alaska, J. Geophys. Res.-Atmos., 97, 1664516660, 1992.
Basiliko, N., Blodau, C., Roehm, C., Bengtson, P., and Moore, T. R.: Regulation of decomposition and methane dynamics across natural, commercially mined, and restored northern peatlands, Ecosystems, 10, 1148-1165, doi:10.1007/S10021-007-9083-2, 2007.

Beer, C., Reichstein, M., Tomelleri, E., Ciais, P., Jung, M., Carvalhais, N., Rodenbeck, C., Arain, M. A., Baldocchi, D., Bonan, G. B., Bondeau, A., Cescatti, A., Lasslop, G., Lindroth, A., Lomas, M., Luyssaert, S., Margolis, H., Oleson, K. W., Roupsard, O., Veenendaal, E., Viovy, N., Williams, C., Woodward, F. I., and Papale, D.: Terrestrial Gross Carbon Dioxide Uptake: Global Distribution and Covariation with Climate, Science, 329, 834838, doi:10.1126/Science.1184984, 2010.

Bellisario, L. M., Bubier, J. L., Moore, T. R., and Chanton, J. P.: Controls on $\mathrm{CH}_{4}$ emissions from a northern peatland, Global Biogeochem. Cy., 13, 81-91, 1999.

Bender, M. and Conrad, R.: Kinetics of $\mathrm{Ch}_{4}$ Oxidation in Oxic Soils Exposed to Ambient Air or High $\mathrm{Ch}_{4}$ Mixing Ratios, Fems Microbiol. Ecol., 101, 261-270, 1992.

Bergamaschi, P., Lowe, D. C., Manning, M. R., Moss, R., Bromley, T., and Clarkson, T. S.: Transects of atmospheric $\mathrm{CO}, \mathrm{CH}_{4}$, and their isotopic composition across the Pacific: Shipboard measurements and validation of inverse models, J. Geophys. Res.Atmos., 106, 7993-8011, 2001.

Bergamaschi, P., Krol, M., Dentener, F., Vermeulen, A., Meinhardt, F., Graul, R., Ramonet, M., Peters, W., and Dlugokencky, E. J.: Inverse modelling of national and European $\mathrm{CH}_{4}$ emissions using the atmospheric zoom model TM5, Atmos. Chem. Phys., 5, 2431-2460, doi:10.5194/acp-5-2431-2005, 2005.

Bergamaschi, P., Frankenberg, C., Meirink, J. F., Krol, M., Dentener, F., Wagner, T., Platt, U., Kaplan, J. O., Korner, S., Heimann, M., Dlugokencky, E. J., and Goede, A.: Satellite chartography of atmospheric methane from SCIAMACHYon board ENVISAT: 2. Evaluation based on inverse model simulations, J. Geophys. Res.-Atmos., 112, D02304, doi:10.1029/2006JD007268, 2007.

Bergamaschi, P., Frankenberg, C., Meirink, J. F., Krol, M., Villani, M. G., Houweling, S., Dentener, F., Dlugokencky, E. J., Miller, J. B., Gatti, L. V., Engel, A., and Levin, I.: Inverse modeling of global and regional $\mathrm{CH}_{4}$ emissions using SCIAMACHY satellite retrievals, J. Geophys. Res.-Atmos., 114, D22301, doi:10.1029/2009JD012287, 2009.

Bergman, I., Svensson, B. H., and Nilsson, M.: Regulation of methane production in a Swedish acid mire by $\mathrm{pH}$, temperature and substrate, Soil Biol. Biochem., 30, 729-741, 1998.

Bloom, A. A., Palmer, P. I., Fraser, A., Reay, D. S., and Frankenberg, C.: Large-Scale Controls of Methanogenesis Inferred from Methane and Gravity Spaceborne Data, Science, 327, 322-325, doi:10.1126/Science.1175176, 2010.

Bohn, T. J., Lettenmaier, D. P., Sathulur, K., Bowling, L. C., Podest, E., McDonald, K. C., and Friborg, T.: Methane emissions from western Siberian wetlands: heterogeneity and sensitivity to climate change, Environ. Res. Lett., 2, 045015, doi:10.1088/17489326/2/4/045015, 2007.

Bonan, G. B., Oleson, K. W., Vertenstein, M., Levis, S., Zeng, X. B., Dai, Y. J., Dickinson, R. E., and Yang, Z. L.: The land surface climatology of the community land model coupled to the NCAR community climate model, J. Climate, 15, 3123-3149, 2002.

Bosse, U. and Frenzel, P.: Activity and distribution of 
methane-oxidizing bacteria in flooded rice soil microcosms and in rice plants (Oryza sativa), Appl. Environ. Microb., 63, 11991207, 1997.

Bousquet, P., Ciais, P., Miller, J. B., Dlugokencky, E. J., Hauglustaine, D. A., Prigent, C., Van der Werf, G. R., Peylin, P., Brunke, E. G., Carouge, C., Langenfelds, R. L., Lathiere, J., Papa, F., Ramonet, M., Schmidt, M., Steele, L. P., Tyler, S. C., and White, J.: Contribution of anthropogenic and natural sources to atmospheric methane variability, Nature, 443, 439-443, 2006.

Bubier, J. L., Crill, P. M., Varner, R. K., and Moore, T. R.: BOREAS TGB-01/TGB-03 $\mathrm{CH}_{4}$ chamber flux data: NSA Fen. Data set, available at: http://www.daac.ornl.gov, Oak Ridge, TN, USA, 1998.

Butler, T. M., Rayner, P. J., Simmonds, I., and Lawrence, M. G.: Simultaneous mass balance inverse modeling of methane and carbon monoxide, J. Geophys. Res.-Atmos., 110, D21310, doi:10.1029/2005JD006071, 2005.

Cao, M., Marshall, S., and Gregson, K.: Global carbon exchange and methane emissions from natural wetlands: Application of a process-based model, J. Geophys. Res., 101, 14399-314414, 1996.

Chanton, J. P. and Whiting, G. J.: Methane stable isotopic distributions as indicators of gas transport mechanisms in emergent aquatic plants, Aquat. Bot., 54, 227-236, 1996.

Chanton, J. P., Whiting, G. J., Happell, J. D., and Gerard, G.: Contrasting Rates and Diurnal Patterns of Methane Emission from Emergent Aquatic Macrophytes, Aquat. Bot., 46, 111-128, 1993.

Chen, Y. H. and Prinn, R. G.: Estimation of atmospheric methane emissions between 1996 and 2001 using a three-dimensional global chemical transport model, J. Geophys. Res.-Atmos., 111, D10307, doi:10.1029/2005JD006058, 2006.

Christensen, T. R., Prentice, I. C., Kaplan, J., Haxeltine, A., and Sitch, S.: Methane flux from northern wetlands and tundra - An ecosystem source modelling approach, Tellus B, 48, 652-661, 1996.

Christensen, T. R., Johansson, T. R., Akerman, H. J., Mastepanov, M., Malmer, N., Friborg, T., Crill, P., and Svensson, B. H.: Thawing sub-arctic permafrost: Effects on vegetation and methane emissions, Geophys. Res. Lett., 31(4), L04501, doi:10.1029/2003g1018680, 2004.

Clarke, L., Edmonds, J., Jacoby, H., Pitcher, H., Reilly, J., and Richels, R.: Scenarios of Greenhouse Gas Emissions and Atmospheric Concentrations. Sub-report 2.1A of Synthesis and Assessment Product 2.1, U.S. Climate Change Science Program and the Subcommittee on Global Change Research, Department of Energy, Office of Biological \& Environmental Research, Washington, DC, USA, 154 pp., 2007.

Clement, R. J., Verma, S. B., and Verry, E. S.: Relating Chamber Measurements to Eddy-Correlation Measurements of Methane Flux, J. Geophys. Res.-Atmos., 100, 21047-21056, 1995.

Colmer, T. D.: Long-distance transport of gases in plants: a perspective on internal aeration and radial oxygen loss from roots, Plant Cell Environ., 26, 17-36, 2003.

Denman, K. L., Brasseur, G., Chidthaisong, A., Ciais, P., Cox, P. M., Dickinson, R. E., Hauglustaine, D. A., Heinze, C., Holland, E., Jacob, E., Lohmann, U., Rmachandran, S., da Silva Dias, P. L., Wofsy, S. C., and Zhang, X.: Couplings between changes in the climate system and biogeochemistry, in: Climate
Change 2007: The physical science basis. Contribution of Working Group I to the Fourth Assessment Report of the Intergovernmental Panel on Climate Change, edited by: Solomon, S., Qin, D., Manning, M., Chen, Z., Marquis, M., Averyt, K. B., Tignor, M., and Miller, H. L., Cambridge University Press, Cambridge, United Kingdom and New York, NY, USA, 512 pp., 2007.

Dentener, F., van Weele, M., Krol, M., Houweling, S., and van Velthoven, P.: Trends and inter-annual variability of methane emissions derived from 1979-1993 global CTM simulations, Atmos. Chem. Phys., 3, 73-88, doi:10.5194/acp-3-73-2003, 2003.

Devol, A. H., Richey, J. E., Forsberg, B. R., and Martinelli, L. A.: Seasonal Dynamics in Methane Emissions from the Amazon River Floodplain to the Troposphere, J. Geophys. Res.-Atmos., 95, 16417-16426, 1990.

Ding, W. X., Cai, Z. C., and Wang, D. X.: Preliminary budget of methane emissions from natural wetlands in China, Atmos. Environ., 38, 751-759, doi:10.1016/J.Atmosenv.2003.10.016, 2004.

Ding, W. X. and Cai, Z. C.: Methane emission from natural wetlands in China: Summary of years 1995-2004 studies, Pedosphere, 17, 475-486, 2007.

Dise, N. B.: Methane Emission from Minnesota Peatlands - Spatial and Seasonal Variability, Global Biogeochem. Cy., 7, 123-142, 1993.

Ferretti, D. F., Miller, J. B., White, J. W. C., Lassey, K. R., Lowe, D. C., and Etheridge, D. M.: Stable isotopes provide revised global limits of aerobic methane emissions from plants, Atmos. Chem. Phys., 7, 237-241, doi:10.5194/acp-7-237-2007, 2007.

Frankenberg, C., Meirink, J. F., Bergamaschi, P., Goede, A. P. H., Heimann, M., Korner, S., Platt, U., van Weele, M., and Wagner, T.: Satellite chartography of atmospheric methane from SCIAMACHY on board ENVISAT: Analysis of the years 2003 and 2004, J. Geophys. Res.-Atmos., 111, D07303, doi:10.1029/2005JD006235, 2006.

Frankenberg, C., Bergamaschi, P., Butz, A., Houweling, S., Meirink, J. F., Notholt, J., Petersen, A. K., Schrijver, H., Warneke, T., and Aben, I.: Tropical methane emissions: A revised view from SCIAMACHY onboard ENVISAT, Geophys Res. Lett., 35, L15811, doi:10.1029/2008GL034300, 2008.

Frenzel, P. and Karofeld, E.: $\mathrm{CH}_{4}$ emission from a hollow-ridge complex in a raised bog: The role of $\mathrm{CH}_{4}$ production and oxidation, Biogeochemistry, 51, 91-112, 2000.

Friedlingstein, P., Cox, P., Betts, R., Bopp, L., Von Bloh, W., Brovkin, V., Cadule, P., Doney, S., Eby, M., Fung, I., Bala, G., John, J., Jones, C., Joos, F., Kato, T., Kawamiya, M., Knorr, W., Lindsay, K., Matthews, H. D., Raddatz, T., Rayner, P., Reick, C., Roeckner, E., Schnitzler, K. G., Schnur, R., Strassmann, K., Weaver, A. J., Yoshikawa, C., and Zeng, N.: Climate-carbon cycle feedback analysis: Results from the (CMIP)-M-4 model intercomparison, J. Climate, 19, 3337-3353, 2006.

Frolking, S. and Crill, P.: Climate Controls on Temporal Variability of Methane Flux from a Poor Fen in Southeastern NewHampshire - Measurement and Modeling, Global Biogeochem. Сy., 8, 385-397, 1994.

Gedney, N., Cox, P. M., and Huntingford, C.: Climate feedback from wetland methane emissions, Geophys. Res. Lett., 31, L20503, doi:10.1029/2004g1020919, 2004.

Gent, P. R., Danabasoglu, G., Donner, L. J., Holland, M. M., Hunke, E. C., Jayne, S. R., Lawrence, D. M., Neale, R. B., Rasch, P J., Vertenstein, M., Worley, P. H., Yang, Z.-L., and Zhang, M.: 
The Community Climate System Model Version 4, J. Climate, doi:10.1175/2011JCLI4083.1, in press, 2011.

Granberg, G., Ottosson-Lofvenius, M., Grip, H., Sundh, I., and Nilsson, M.: Effect of climatic variability from 1980 to 1997 on simulated methane emission from a boreal mixed mire in northern Sweden, Global Biogeochem. Cy., 15, 977-991, 2001.

Grant, R. F.: Simulation of methanogenesis in the mathematical model ecosys, Soil Biol. Biochem., 30, 883-896, 1998.

Grant, R. F.: Simulation of methanotrophy in the mathematical model ecosys, Soil Biol. Biochem., 31, 287-297, 1999.

Grant, R. F. and Roulet, N. T.: Methane efflux from boreal wetlands: Theory and testing of the ecosystem model Ecosys with chamber and tower flux measurements, Global Biogeochem. Сy., 16, 1054, doi:10.1029/2001gb001702, 2002.

Grunfeld, S. and Brix, H.: Methanogenesis and methane emissions: effects of water table, substrate type and presence of Phragmites australis, Aquat. Bot., 64, 63-75, 1999.

Gulledge, J. and Schimel, J. P.: Moisture control over atmospheric $\mathrm{CH}_{4}$ consumption and $\mathrm{CO}_{2}$ production in diverse Alaskan soils, Soil Biol. Biochem., 30, 1127-1132, 1998.

Hinzman, L. D., Kane, D. L., Gieck, R. E., and Everett, K. R.: Hydrologic and Thermal-Properties of the Active Layer in the Alaskan Arctic, Cold Reg. Sci. Technol., 19, 95-110, 1991.

Houweling, S., Kaminski, T., Dentener, F., Lelieveld, J., and Heimann, M.: Inverse modeling of methane sources and sinks using the adjoint of a global transport model, J. Geophys. Res.Atmos., 104, 26137-26160, 1999.

Houweling, S., Dentener, F., and Lelieveld, J.: Simulation of preindustrial atmospheric methane to constrain the global source strength of natural wetlands, J. Geophys. Res.-Atmos., 105, 17243-17255, 2000.

Houweling, S., Rockmann, T., Aben, I., Keppler, F., Krol, M., Meirink, J. F., Dlugokencky, E. J., and Frankenberg, C.: Atmospheric constraints on global emissions of methane from plants, Geophys. Res. Lett., 33, L15821, doi:10.1029/2006GL026162, 2006.

Iiyama, I. and Hasegawa, S.: Gas diffusion coefficient of undisturbed peat soils, Soil Sci. Plant Nutr., 51, 431-435, 2005.

IPCC: Climate Change 2007: The Physical Science Basis. Contribution of Working Group I to the Fourth Assessment Report of the IPCC, edited by: Solomon, S., Qin, D., Manning, M., Chen, Z., Marquis, M., Averyt, K. B., Tignor, M., and Miller, H. L., Cambridge University Press, Cambridge, United Kingdom and New York, 2007.

Kai, F. M., Tyler, S. C., Randerson, J. T., and Blake, D. R.: Reduced methane growth rate explained by decreased Northern Hemisphere microbial sources, Nature, in press, 2010.

Kaplan, J. O.: Wetlands at the Last Glacial Maximum: Distribution and methane emissions, Geophys. Res. Lett., 29, 1079, doi:10.1029/2001g1013366, 2002.

Karlsdottir, S. and Isaksen, I. S. A.: Changing methane lifetime: Possible cause for reduced growth, Geophys. Res. Lett., 27, 9396, 2000.

Keller, M. M.: Biological sources and sinks of methane in tropical habitats and tropical atmospheric chemistry, Princeton University, 1990 .

Kellner, E., Baird, A. J., Oosterwoud, M., Harrison, K., and Waddington, J. M.: Effect of temperature and atmospheric pressure on methane $\left(\mathrm{CH}_{4}\right)$ ebullition from near-surface peats, Geo- phys. Res. Lett., 33, L18405, doi:10.1029/2006g1027509, 2006.

Keppler, F.: Aerobic methane formation in plants, Geochim. Cosmochim. Ac., 73, A641-A641, 2009.

Keppler, F., Hamilton, J. T. G., Brass, M., and Rockmann, T.: Methane emissions from terrestrial plants under aerobic conditions, Nature, 439, 187-191, doi:10.1038/Nature04420, 2006.

Khalil, M. A. K. and Shearer, M. J.: Sources of methane: An overview, in: Atmospheric methane: Its role in the global environment, edited by: Khalil, M. A. K., Springer, New York, NY, 98-111, 2000.

King, G. M.: Responses of atmospheric methane consumption by soils to global climate change, Glob. Change Biol., 3, 351-362, 1997.

Koh, H. S., Ochs, C. A., and Yu, K. W.: Hydrologic gradient and vegetation controls on $\mathrm{CH}_{4}$ and $\mathrm{CO}_{2}$ fluxes in a spring-fed forested wetland, Hydrobiologia, 630, 271-286, doi:10.1007/S10750-009-9821-X, 2009.

Kort, E. A., Eluszkiewicz, J., Stephens, B. B., Miller, J. B., Gerbig, C., Nehrkorn, T., Daube, B. C., Kaplan, J. O., Houweling, S., and Wofsy, S. C.: Emissions of $\mathrm{CH}_{4}$ and $\mathrm{N}_{2} \mathrm{O}$ over the United States and Canada based on a receptor-oriented modeling framework and COBRA-NA atmospheric observations, Geophys. Res. Lett., 35, L18808, doi:10.1029/2008GL034031, 2008.

Lawrence, D. M. and Slater, A. G.: Incorporating organic soil into a global climate model, Clim. Dynam., 30, 145-160, doi:10.1007/S00382-007-0278-1, 2008.

Lawrence, D. M., Thornton, P. E., Oleson, K. W., and Bonan, G. B.: The partitioning of evapotranspiration into transpiration, soil evaporation, and canopy evaporation in a GCM: Impacts on landatmosphere interaction, J. Hydrometeorol., 8, 862-880, 2007.

Lawrence, D. M., Slater, A. G., Romanovsky, V. E., and Nicolsky, D. J.: Sensitivity of a model projection of near-surface permafrost degradation to soil column depth and representation of soil organic matter, Journal of Geophys. Res.-Earth, 113(14), F02011, doi:10.1029/2007jf000883, 2008.

Lawrence, D. M., Oleson, K. W., Flanner, M. G., Thornton, P. E., Swenson, S. C., Lawrence, P. J., Zeng, X., Yang, Z.-L., Levis, S., Sakaguchi, K., Bonan, G. B., and Slate., A. G.: Parameterization improvements and functional and structural advances in version 4 of the Community Land Model, J. Adv. Model. Earth Sys., 3, M03001, doi:10.1029/2011MS000045, 2011.

Le Mer, J. and Roger, P.: Production, oxidation, emission and consumption of methane by soils: A review, Eur. J. Soil Biol., 37, 25-50, 2001.

Lehner, B. and Doll, P.: Development and validation of a global database of lakes, reservoirs and wetlands, J. Hydrol., 296, 1-22, doi:10.1016/J.Jhydrol.2004.03.028, 2004.

Lerman, A.: Geochemical processes: Water and sediment environments, John Wiley and Sons, New York, N.Y., 1979.

Letts, M. G., Roulet, N. T., Comer, N. T., Skarupa, M. R., and Verseghy, D. L.: Parametrization of peatland hydraulic properties for the Canadian Land Surface Scheme, Atmos. Ocean, 38, 141-160, 2000.

Lloyd, J. and Taylor, J. A.: On the temperature dependence of soil respiration, Funct. Ecol., 8, 315-323, 1994.

MacDonald, G. M., Beilman, D. W., Kremenetski, K. V., Sheng, Y. W., Smith, L. C., and Velichko, A. A.: Rapid early development of circumarctic peatlands and atmospheric $\mathrm{CH}_{4}$ and $\mathrm{CO}_{2}$ variations, Science, 314, 285-288, doi:10.1126/science.1131722, 
2006.

Mastepanov, M., Sigsgaard, C., Dlugokencky, E. J., Houweling, S., Strom, L., Tamstorf, M. P., and Christensen, T. R.: Large tundra methane burst during onset of freezing, Nature, 456, 628-630, doi:10.1038/nature07464, 2008.

Matthews, E. and Fung, I.: Methane emission from natural wetlands: global distributions, area and environmental characteristics of sources, Global Biogeochem. Cy., 1, 61-86, 1987.

Megonigal, J. P., Hines, M. E., and Visscher, P. T.: Anaerobic Metabolism: Linkages to Trace Gases and Aerobic Processes, in: Biogeochemistry, edited by: Schlesinger, W. H., ElsevierPergamon, Oxford, UK, 317-424, 2004.

Meirink, J. F., Eskes, H. J., and Goede, A. P. H.: Sensitivity analysis of methane emissions derived from SCIAMACHY observations through inverse modelling, Atmos. Chem. Phys., 6, 1275-1292, doi:10.5194/acp-6-1275-2006, 2006.

Meirink, J. F., Bergamaschi, P., Frankenberg, C., d'Amelio, M. T. S., Dlugokencky, E. J., Gatti, L. V., Houweling, S., Miller, J. B., Rockmann, T., Villani, M. G., and Krol, M. C.: Fourdimensional variational data assimilation for inverse modeling of atmospheric methane emissions: Analysis of SCIAMACHY observations, J. Geophys. Res.-Atmos., 113, D17301, doi:10.1029/2007JD009740, 2008a.

Meirink, J. F., Bergamaschi, P., and Krol, M. C.: Fourdimensional variational data assimilation for inverse modelling of atmospheric methane emissions: method and comparison with synthesis inversion, Atmos. Chem. Phys., 8, 6341-6353, doi:10.5194/acp-8-6341-2008, 2008b.

Meng, L., Hess, P. G. M., Mahowald, N. M., Yavitt, J. B., Riley, W. J., Subin, Z. M., Lawrence, D. M., Swenson, S. C., Jauhiainen, J., and Fuka, D. R.: Sensitivity of wetland methane emissions to model assumptions: application and model testing against site observations, Biogeosciences Discuss., 8, 60956160, doi:10.5194/bgd-8-6095-2011, 2011.

Millington, R. and Quirk, J. P.: Permeability of Porous Solids, T. Faraday Soc., 57, 1200-1207, 1961.

Moldrup, P., Olesen, T., Komatsu, T., Yoshikawa, S., Schjonning, P., and Rolston, D. E.: Modeling diffusion and reaction in soils: $\mathrm{X}$. A unifying model for solute and gas diffusivity in unsaturated soil, Soil Sci., 168, 321-337, 2003.

Moore, T. R. and Roulet, N. T.: Methane Flux - Water-Table Relations in Northern Wetlands, Geophys. Res. Lett., 20, 587-590, 1993.

Morrissey, L. A., Zobel, D. B., and Livingston, G. P.: Significance of Stomatal Control on Methane Release from Carex-Dominated Wetlands, Chemosphere, 26, 339-355, 1993.

Nisbet, R. E. R., Fisher, R., Nimmo, R. H., Bendall, D. S., Crill, P. M., Gallego-Sala, A. V., Hornibrook, E. R. C., LopezJuez, E., Lowry, D., Nisbet, P. B. R., Shuckburgh, E. F., Sriskantharajah, S., Howe, C. J., and Nisbet, E. G.: Emission of methane from plants, P. R. Soc. B, 276, 1347-1354, doi:10.1098/Rspb.2008.1731, 2009.

Niu, G. Y., Yang, Z. L., Dickinson, R. E., and Gulden, L. E.: A simple TOPMODEL-based runoff parameterization (SIMTOP) for use in global climate models, J. Geophys. Res.-Atmos., 110, D21106, doi:10.1029/2005jd006111, 2005.

Oleson, K. W., Niu, G. Y., Yang, Z. L., Lawrence, D. M., Thornton, P. E., Lawrence, P. J., Stockli, R., Dickinson, R. E., Bonan, G. B., Levis, S., Dai, A., and Qian, T.: Improvements to the Community
Land Model and their impact on the hydrological cycle, J. Geophys. Res.-Biogeo., 113, G01021, doi:10.1029/2007jg000563, 2008.

Oleson, K. W., Lawrence, D. M., Bonan, G. B., Flanner, M. G., Kluzek, E., Lawrence, P. J., Levis, S., Swenson, S. C., Thornton, P. E., Dai, A., Decker, M., Dickinson, R., Feddema, J., Heald, C. L., Hoffman, F., Lamarque, J.-F., Mahowald, N., Niu, G.-Y., Qian, T., Randerson, J., Running, S., Sakaguchi, K., Slater, A., Stockli, R., Wang, A., Yang, Z.-L., Zeng, X., and Zeng, X.: Technical Description of version 4.0 of the Community Land Model (CLM), National Center for Atmospheric Research, Boulder, CONCAR Technical Note NCAR/TN-478+STR, 257 pp., 2010.

Petrescu, A. M. R., van Beek, E. J. R., van Huissteden, J., Prigent, C., Sachs, T., Corradi, C. A. R., Parmentier, F. J. W., and Dolman, A. J.: Modeling regional to global $\mathrm{CH}_{4}$ emissions of boreal and arctic wetlands, Global Biogeochem. Cy., 24, GB4009, doi:10.1029/2009GB003610, 2010.

Potter, C., Klooster, S., Hiatt, S., Fladeland, M., Genovese, V., and Gross, P.: Methane emissions from natural wetlands in the United States: Satellite-derived estimation based on ecosystem carbon cycling, Earth Interact., 10, 1-12, 2006.

Potter, C. S.: An ecosystem simulation model for methane production and emission from wetlands, Global Biogeochem. Cy., 11, 495-506, 1997.

Press, W., Flannery, B., Teukolsky, S., and Vetterling, W.: Numerical Recipes (FORTRAN), Cambridge Univ. Press, New York, NY, 702 pp., 1989.

Prigent, C., Papa, F., Aires, F., Rossow, W. B., and Matthews, E.: Global inundation dynamics inferred from multiple satellite observations, 1993-2000, J. Geophys. Res.-Atmos., 112, D12107, doi:10.1029/2006JD007847, 2007.

Qian, T. T., Dai, A., Trenberth, K. E., and Oleson, K. W.: Simulation of global land surface conditions from 1948 to 2004. Part I: Forcing data and evaluations, J. Hydrometeorol., 7, 953-975, 2006.

Randerson, J. T., Hoffman, F. M., Thornton, P. E., Mahowald, N. M., Lindsay, K., Lee, Y. H., Nevison, C. D., Doney, S. C., Bonan, G., Stockli, R., Covey, C., Running, S. W., and Fung, I. Y.: Systematic assessment of terrestrial biogeochemistry in coupled climate-carbon models, Glob. Change Biol., 15, 2462-2484, doi:10.1111/J.1365-2486.2009.01912.X, 2009.

Rappoldt, C. and Crawford, J. W.: The distribution of anoxic volume in a fractal model of soil, Geoderma, 88, 329-347, 1999.

Rice, A. L., Butenhoff, C. L., Shearer, M. J., Teama, D., Rosenstiel, T. N., and Khalil, M. A. K.: Emissions of anaerobically produced methane by trees, Geophys. Res. Lett., 37, L03807, doi:10.1029/2009g1041565, 2010.

Ridgwell, A. J., Marshall, S. J., and Gregson, K.: Consumption of atmospheric methane by soils: A process-based model, Global Biogeochem. Cy., 13, 59-70, 1999.

Saarnio, S., Alm, J., Silvola, J., Lohila, A., Nykanen, H., and Martikainen, P. J.: Seasonal variation in $\mathrm{CH}_{4}$ emissions and production and oxidation potentials at microsites on an oligotrophic pine fen, Oecologia, 110, 414-422, 1997.

Schimel, J. P.: Plant-Transport and Methane Production as Controls on Methane Flux from Arctic Wet Meadow Tundra, Biogeochemistry, 28, 183-200, 1995.

Schnell, S. and King, G. M.: Responses of methanotrophic activity 
in soils and cultures to water stress, Appl. Environ. Microb., 62, 3203-3209, 1996.

Schurgers, G., Dorsch, P., Bakken, L., Leffelaar, P., and Haugen, L. E.: Modelling soil anaerobiosis from water retention characteristics and soil respiration, Soil Biol. Biochem., 38, 2637-2644, doi:10.1016/J.Soilbio.2006.04.016, 2006.

Schuur, E. A. G., Bockheim, J., Canadell, J. G., Euskirchen, E., Field, C. B., Goryachkin, S. V., Hagemann, S., Kuhry, P., Lafleur, P. M., Lee, H., Mazhitova, G., Nelson, F. E., Rinke, A., Romanovsky, V. E., Shiklomanov, N., Tarnocai, C., Venevsky, S., Vogel, J. G., and Zimov, S. A.: Vulnerability of permafrost carbon to climate change: Implications for the global carbon cycle, Bioscience, 58, 701-714, 2008.

Schuur, E. A. G., Vogel, J. G., Crummer, K. G., Lee, H., Sickman, J. O., and Osterkamp, T. E.: The effect of permafrost thaw on old carbon release and net carbon exchange from tundra, Nature, 459, 556-559, 2009.

Segers, R.: Methane production and methane consumption: a review of processes underlying wetland methane fluxes, Biogeochemistry, 41, 23-51, 1998.

Segers, R. and Kengen, S. W. M.: Methane production as a function of anaerobic carbon mineralization: A process model, Soil Biol. Biochem., 30, 1107-1117, 1998.

Segers, R. and Leffelaar, P. A.: Modeling methane fluxes in wetlands with gas-transporting plants 1 . Single-root scale, J. Geophys. Res.-Atmos., 106, 3511-3528, 2001a.

Segers, R. and Leffelaar, P. A.: Modeling methane fluxes in wetlands with gas-transporting plants 3. Plot scale, J. Geophys. Res.Atmos., 106, 3541-3558, 2001b.

Segers, R., Rappoldt, C., and Leffelaar, P. A.: Modeling methane fluxes in wetlands with gas-transporting plants 2 . Soil layer scale, J. Geophys. Res.-Atmos., 106, 3529-3540, 2001.

Shannon, R. D. and White, J. R.: 3-Year Study of Controls on Methane Emissions from 2 Michigan Peatlands, Biogeochemistry, 27, 35-60, 1994.

Shindell, D. T., Walter, B. P., and Faluvegi, G.: Impacts of climate change on methane emissions from wetlands, Geophys. Res. Lett., 31, L21202, , 2004.

Smith, K. A., Ball, T., Conen, F., Dobbie, K. E., Massheder, J., and Rey, A.: Exchange of greenhouse gases between soil and atmosphere: interactions of soil physical factors and biological processes, Eur. J. Soil Sci., 54, 779-791, doi:10.1046/j.13510754.2003.0567.x, 2003.

Smith, L. K., Lewis, W. M., Chanton, J. P., Cronin, G., and Hamilton, S. K.: Methane emissions from the Orinoco River floodplain, Venezuela, Biogeochemistry, 51, 113-140, 2000.

Snover, A. K. and Quay, P. D.: Hydrogen and carbon kinetic isotope effects during soil uptake of atmospheric methane, Global Biogeochem. Cy., 14, 25-39, 2000.

Stockli, R., Lawrence, D. M., Niu, G. Y., Oleson, K. W., Thornton, P. E., Yang, Z. L., Bonan, G. B., Denning, A. S., and Running, S. W.: Use of FLUXNET in the community land model development, J. Geophys. Res.-Biogeo., 113, G01025, doi:10.1029/2007jg000562, 2008.

Strack, M., Kellner, E., and Waddington, J. M.: Effect of entrapped gas on peatland surface level fluctuations, Hydrol. Process., 20, 3611-3622, doi:10.1002/Hyp.6518, 2006.

Straume, A. G., Schrijver, H., Gloudemans, A. M. S., Houweling, S., Aben, I., Maurellis, A. N., de Laat, A. T. J., Kleipool,
Q., Lichtenberg, G., van Hees, R., Meirink, J. F., and Krol, M.: The global variation of $\mathrm{CH}_{4}$ and $\mathrm{CO}$ as seen by SCIAMACHY, Atmospheric Remote Sensing: Earth's Surface, Troposphere, Stratosphere and Mesosphere - I, 36, 821-827, 2005.

Svensson, B. H., Christensen, T. R., Johansson, E., and Oquist, M.: Interdecadal changes in $\mathrm{CO}_{2}$ and $\mathrm{CH}_{4}$ fluxes of a subarctic mire: Stordalen revisited after 20 years, Oikos, 85, 22-30, 1999.

Thornton, P. E., Lamarque, J. F., Rosenbloom, N. A., and Mahowald, N. M.: Influence of carbon-nitrogen cycle coupling on land model response to $\mathrm{CO}_{2}$ fertilization and climate variability, Global Biogeochem. Cy., 21, Gb4018, doi:10.1029/2006gb002868, 2007.

Tian, H., Xu, X., Liu, M., Ren, W., Zhang, C., Chen, G., and Lu, C.: Spatial and temporal patterns of $\mathrm{CH}_{4}$ and $\mathrm{N}_{2} \mathrm{O}$ fluxes in terrestrial ecosystems of North America during 1979-2008: application of a global biogeochemistry model, Biogeosciences, 7, 2673-2694, doi:10.5194/bg-7-2673-2010, 2010.

Torn, M. S. and Chapin, F. S.: Environmental and Biotic Controls over Methane Flux from Arctic Tundra, Chemosphere, 26, 357368, 1993.

van Huissteden, J., Petrescu, A. M. R., Hendriks, D. M. D., and Rebel, K. T.: Sensitivity analysis of a wetland methane emission model based on temperate and arctic wetland sites, Biogeosciences, 6, 3035-3051, doi:10.5194/bg-6-3035-2009, 2009.

Verma, A., Arkebauer, T. J., and Valentine, D.: BOREAS TF-11 $\mathrm{CO}_{2}$ and $\mathrm{CH}_{4}$ flux data from the SSA-Fen. Data set, available at: http://www.daac.ornl.gov, Oak Ridge, TN, USA, 1998.

Volodin, E. M.: Methane cycle in the INM RAS climate model, Izv. Atmos. Ocean. Phy.t, 44, 153-159, doi:10.1134/S0001433808020023, 2008.

Walter, B. P. and Heimann, M.: A process-based, climate-sensitive model to derive methane emissions from natural wetlands: Application to five wetland sites, sensitivity to model parameters, and climate, Global Biogeochem. Cy., 14, 745-765, 2000.

Walter, B. P., Heimann, M., and Matthews, E.: Modeling modern methane emissions from natural wetlands 1 . Model description and results, J. Geophys. Res.-Atmos., 106, 34189-34206, 2001a.

Walter, B. P., Heimann, M., and Matthews, E.: Modeling modern methane emissions from natural wetlands 2 . Interannual variations 1982-1993, J. Geophys. Res.-Atmos., 106, 34207-34219, 2001b.

Walter, K. M., Smith, L. C., and Chapin, F. S.: Methane bubbling from northern lakes: present and future contributions to the global methane budget, Philos. T. R. Soc., 365, 1657-1676, doi:10.1098/rsta.2007.2036, 2007.

Wania, R., Ross, I., and Prentice, I. C.: Integrating peatlands and permafrost into a dynamic global vegetation model: 2. Evaluation and sensitivity of vegetation and carbon cycle processes, Global Biogeochem. Cy., 23, Gb3015, doi:10.1029/2008gb003413, 2009.

Wania, R., Ross, I., and Prentice, I. C.: Implementation and evaluation of a new methane model within a dynamic global vegetation model: LPJ-WHyMe v1.3.1, Geosci. Model Dev., 3, 565-584, doi:10.5194/gmd-3-565-2010, 2010.

Wassmann, R., Thein, U. G., Whiticar, M. J., Rennenberg, H., Seiler, W., and Junk, W. J.: Methane emissions from the Amazon floodplain: Characterization of production and transport, Global Biogeochem. Cy., 6, 3-13, 1992.

Whalen, S. C.: Biogeochemistry of methane exchange between 
natural wetlands and the atmosphere, Environ. Eng. Sci., 22, 7394, 2005.

Whalen, S. C. and Reeburgh, W. S.: Interannual variations in tundra methane emission: a 4-year time series at fixed sites., Global Biogeochem. Cy., 6, 139-159, 1992.

Whalen, S. C. and Reeburgh, W. S.: Moisture and temperature sensitivity of $\mathrm{CH}_{4}$ oxidation in boreal soils, Soil Biol. Biochem., 28, 1271-1281, 1996.

Whiting, G. J. and Chanton, J. P.: Control of the diurnal pattern of methane emission from emergent aquatic macrophytes by gas transport mechanisms, Aquat. Bot., 54, 237-253, 1996.

Zhang, Y., Li, C. S., Trettin, C. C., Li, H., and Sun, G.: An integrated model of soil, hydrology, and vegetation for carbon dynamics in wetland ecosystems, Global Biogeochem. Cy., 16, 1061, doi:10.1029/2001gb001838, 2002.

Zhuang, Q., Melillo, J. M., Kicklighter, D. W., Prinn, R. G., McGuire, A. D., Steudler, P. A., Felzer, B. S., and Hu, S.: Methane fluxes between terrestrial ecosystems and the atmosphere at northern high latitudes during the past century: A retrospective analysis with a process-based biogeochemistry model, Global Biogeochem. Cy., 18, GB3010, doi:10.1029/2004GB002239, 2004.
Zhuang, Q. L., Melillo, J. M., Sarofim, M. C., Kicklighter, D. W., McGuire, A. D., Felzer, B. S., Sokolov, A., Prinn, R. G., Steudler, P. A., and $\mathrm{Hu}, \mathrm{S}$. M.: $\mathrm{CO}_{2}$ and $\mathrm{CH}_{4}$ exchanges between land ecosystems and the atmosphere in northern high latitudes over the 21 st century, Geophys. Res. Lett., 33(5), L17403, doi:10.1029/2006g1026972, 2006.

Zona, D., Oechel, W. C., Kochendorfer, J., Paw U, K. T., Salyuk, A. N., Olivas, P. C., Oberbauer, S. F., and Lipson, D. A.: Methane fluxes during the initiation of a large-scale water table manipulation experiment in the Alaskan Arctic tundra, Global Biogeochem. Cy., 23, Gb2013, doi:10.1029/2009gb003487, 2009. 